\title{
The three great issues confronting Europe - economic, environmental and political
}

\author{
Jan Fagerberg1, Staffan Laestadius ${ }^{2}$ and Ben R. Martin ${ }^{3}$ \\ ${ }^{1}$ TIK, University of Oslo; ${ }^{2}$ Royal Institute of Technology, Stockholm; ${ }^{3}$ SPRU, University of Sussex \\ Chapter 15 in J. Niosi (ed.), Innovation Policy, Systems and Management, Cambridge \\ University Press, Cambridge, pp.464-491.
}

\begin{abstract}
Europe is confronted by an intimidating triple challenge - economic stagnation, climate change, and a governance crisis. This paper demonstrates how the three challenges are closely interrelated, and discusses how they can be dealt with more effectively in order to arrive at a more economically secure, environmentally sustainable and well governed Europe. In particular, a return to classic economic growth cannot come at the expense of greater risk of irreversible climate change. Instead, what is required is a fundamental transformation of the economy to a new 'green' trajectory based on rapidly diminishing emission of greenhouse gases. Following this path would mean turning Europe into a veritable laboratory for sustainable growth, environmentally as well as socially.
\end{abstract}

Keywords: Europe, European Union, triple challenge, economic stagnation, climate change, governance crisis, innovation policy, transformation process 


\section{Introduction}

Europe today is confronted by fundamental changes in its external environment as well as internally, giving rise to several daunting policy challenges. First, there is the economic challenge manifest in slow growth or even stagnation in many countries, which, although also present in other parts of the world, is particularly severe in Europe. Second, there is the challenge posed by the climate crisis, the solution of which requires nothing less than a fundamental transformation from carbon-based growth to a new, sustainable economy. Without it future generations will be in dire straits. The third challenge concerns the governance and policy crisis now facing Europe and the difficulties this poses for policy making and implementation. It may be argued that the recent and rapid growth of immigration to Europe is a fourth challenge. Although we do not deny the institutional challenges, in particular since 2015 , faced by many European countries from that situation our conjecture is that learning to cope with the three main challenges analysed below will be essential in our long term capacity to absorb new Europeans. In addition it should be noticed that Europe just absorbs a fraction of the growing global migration (GMDAC, 2016). This paper argues that a completely new policy stance is required, one that simultaneously addresses the challenges brought about by economic stagnation, by climate change, and by governance.

\section{The Economic Challenge for Europe}

Over the longer term, European economic integration has delivered very substantial benefits to Europe's citizens. For example, during the first two or three decades of integration efforts in (Western) Europe the economy grew very fast, and the gap in productivity and income vis-à-vis 
the world's technologically and economically leading country, the United States, was considerably reduced (Abramovitz, 1994). The European Union has also been notably successful in supporting transitions from authoritarian regimes to democracy in large parts of Europe, first from the mid-1970s onwards when the fascist dictatorships in Southern Europe were swept away, and once more - and on a much larger scale - in the 1990s onwards following the disintegration of the former Soviet Union. The gradual integration of the countries in Eastern Europe, followed by substantial inflows of investment from the rest of Europe, led to very rapid growth in the new member countries and markedly reduced differences in productivity and income across Europe as a whole (Fagerberg and Verspagen 2015).

Around the turn of the millennium, several European initiatives were taken to sustain the positive dynamics of the previous decades in the expectation that this would lead to a further narrowing of the gap in GDP per capita between the US and Europe. For example, at the EU summits in Lisbon and Barcelona in 2000 and 2002, Member States agreed on the goal of making Europe "the most competitive and dynamic knowledge-based economy in the world capable of sustainable economic growth with more and better jobs and greater social cohesion" by increasing R\&D investments (as a share of GDP) to a level superior to that of the USA by the end of the decade. ${ }^{1}$ Moreover, a common European currency, the Euro, was introduced in 2002 as part of the strategy to further deepen European integration and spur economic growth.

1 See http://www.consilium.europa.eu/en/uedocs/cms_data/docs/pressdata/en/ec/00100-r1.en0.htm (accessed on 22 January 2015). 


\section{(Figure 1 here)}

To what extent did European policy makers succeed in their aims? Figure 1 traces the development of GDP per capita from mid 1990s onwards for three groups of European countries and the EU as whole relative to that of the United States. ${ }^{2}$ As the figure shows there is little evidence of Europe catching up with the US during this period. In fact, in 2015 GDP per capita in the European Union was two thirds of the US level, exactly the same as twenty years earlier. Among the European countries, only the new members from the East of Europe managed to substantially reduce the productivity gap with respect to the US, rising from $32 \%$ to $46 \%$ of the US level between 2000 and 2008, after which the catch-up of Eastern Europe came to an abrupt halt. In Southern Europe the average GDP per capita relative to that of the USA was roughly constant and equal to the EU average until the outbreak of the financial crisis. However, between 2008 and 2015 it dropped from $66 \%$ to 56\% of the US level, a 15 per cent decline compared to the pre-crisis level. Thus, rather than the convergence in GDP per capita that characterized Europe during the previous decade, the years after 2007-8 have witnessed a process of divergence, with several countries, particularly in the Southern part of the continent, falling further behind economically.

2 Germany is included in the "North" together with the Nordic EU-member countries and the Netherlands. The Southern countries are Greece, Italy, Portugal and Spain, while the Eastern group consists of the eleven member countries formerly part of, or dominated by, the Soviet Union. 
(Figure 2 here)

Should we be concerned about these developments? Yes - and to see why, consider Figure 2, which shows the change in unemployment rates for young adults aged 20-24 in Europe since the crisis struck. Apart from a few countries (and especially Germany), youth unemployment has been on the increase everywhere. The situation is especially severe in Southern Europe, where the level of youth unemployment has more than doubled compared to the situation before the financial crisis, and in parts of Eastern Europe. If this situation is not reversed, large numbers of young people in Europe risk being permanently marginalized, the social, economic and political consequences of which are likely to be highly detrimental to Europe's future.

Why is Europe's performance so disappointing? The economic changes that have taken place in Europe during the last two or three decades have occurred within an international context characterized by globalization. The gradual inclusion of China in the global capitalist economy, adding hundreds of millions of lower-paid manufacturing workers to the global labour pool, provided a substantial boost to this process, and similar although less spectacular developments have taken place in other developing nations. This process also poses a challenge, however, because it tends to undermine the competitive position of established industries throughout the developed world, especially in low skill, labour-intensive manufacturing processes. The evidence (Fagerberg and Verspagen, 2015; Landesmann, 2015) suggests that the effects of globalization on the growth performance of different parts of Europe have been very uneven. While the advanced economies in the North of Europe have to 
a certain extent managed to adapt to the changing competitive conditions, by selling advanced products to customers in emerging markets (and substantially increasing their exports as a percentage of GDP), countries in the Southern part of the continent (and some in the East) have generally failed to do so. Hence, they became 'losers' in the globalization process.

However, European integration - and policies - have also had an impact. The introduction of the Euro in 2002 meant that the economies of the Euro-zone became more interdependent. A natural consequence of this might well have been a greater degree of coordination of economic policies among the participating countries, but instead the Euro-zone countries continued to shape their economic policies based largely on domestic considerations, effectively disregarding the consequences for other countries and the wider Euro-zone. For example, Germany, following the costly re-unification with former East Germany, decided to restrain growth in wages and domestic demand in order to boost the competitiveness of its industry and to run a trade surplus with the rest of the world. However, this policy implied that other, less competitive members of the Euro-zone, with less scope for growing through increasing exports, would have to practice austerity as well if increasing trade deficits were to be avoided. Initially, several countries in the South shied away from austerity, leading to increasing deficits and rising foreign indebtedness (Fagerberg and Verspagen, 2015; Landesmann, 2015), a situation which clearly was not sustainable. However, eventually the financial crisis brought governments in different parts of Europe together under the umbrella of austerity, leading to slow growth, rising unemployment (especially in the South) and increasing divergence in the Union as whole. 


\section{Europe facing the Climate Challenge}

There is consensus among climate analysts that the globe is currently heading towards a $3-6^{\circ} \mathrm{C}$ warmer Earth than a century ago, and that this global warming is primarily caused by greenhouse gas (GHG) emissions from human activities (IPCC, 2012, 2013a,b \& 2014; World Bank, 2012 \& 2013).. In order to confine temperature rises to $2^{\circ} \mathrm{C}$, global $\mathrm{GHG}$ emissions have to be reduced substantially by 2050 , and almost completely eliminated by the end of the century (IPCC, 2014). These demanding goals, are equivalent to annual reductions by approximately 3-4\% annually for the rest of this century (cf. e.g. Smil, 2010). More recent analyses deliver a still tougher message: to have a real impact on climate change - i.e. to provide a reasonable chance to keep temperature increase below $2^{\circ} \mathrm{C}$, or even $1.5^{\circ} \mathrm{C}$ - global GHG-emissions (also non-energy related) must decline in a magnitude of 5-6 \% annually from present levels for the decades ahead, leaving less of the reduction to the second half of the century (IEA, 2015b, Reilly et al, 2015). However, global $\mathrm{CO}_{2}$ emissions still increase on a global level and have done so every year since 2009 (BP, 2016b). In addition, it would seem only reasonable that the developed part of the world, which has benefitted most from previous emissions, should shoulder the largest burden of the reductions ahead.

European politicians pride themselves on having already substantially reduced greenhouse-gas emissions and hence for being on broadly the right track (European Council, 2014). But is this correct? To explore this, Figure 3 traces the development of European GHG emissions from 1990 onwards for three country groups: Eastern Europe, Germany (including the former GDR) and the rest of Europe. 
(Figure 3 here)

What the figure shows is that, for Europe as a whole, there was a reduction in emissions in the early 1990s, but this can be almost entirely explained by the rapid changes that took place (including the closure of inefficient plants) in the previously socialist countries in the East. For the rest of Europe, emissions were essentially stable until the outbreak of the financial crisis. This raises the question whether the more recent decline in GHG emissions represents a shift towards a new, more sustainable path, or whether it is mainly a consequence of the financial crisis, and hence is likely to be reversed should the economy recover.

To investigate this, Figure 4 includes data on GHG emissions and growth of GDP for the European Union as a whole between 1995 and 2012. It reveals that the GHG intensity (i.e. GHG emissions per unit of output) has declined steadily, as it has in the US (Nordhaus, 2013). But until shortly before the financial crisis, this decline was not enough to reduce Europe's emissions. Moreover, as the figure shows, had growth continued at the same pace as before the crisis, emissions would probably have stayed roughly constant. Thus, the recent decline in emissions does not reflect a change towards a more sustainable path for the European economy, but is mainly a reflection of continuing economic stagnation. And, following recent BP statistics, in 2015 the European $\mathrm{CO}_{2}$ emissions turned upwards again potentially indicating that the growth effect now more than compensates for increased carbon efficiency (BP, 2016b). In fact European consumption of oil and natural gas in 2015 increased with $1.5 \%$ and $4.6 \%$ 
respectively which - from an emission perspective - more than compensated for the decline in coal consumption with $1.8 \%$ (BP, 2016a).

\section{(Figure 4 here)}

This raises serious questions about Europe's ability to cope with the challenges discussed in this chapter. A revival of the economy, which is required to reduce unemployment and increase welfare, appears to be in direct conflict with the need to combat climate change. Or to put it differently, to realize both objectives, the European economy has to be shifted to a completely new trajectory when it comes to the emission of greenhouse gases. For example, to allow for 'classic' economic growth of $1.5 \%$ per year for Europe as a whole, the annual decline in the GHG intensity needs to be around 6-7\% per year during the decades ahead. This is a truly formidable challenge and will require a fundamental transformation of the content of European economic activities.

In October 2014, EU leaders met to consider European policies on climate change and agreed to reduce GHG emissions by 40\% (compared to the 1990 level) by 2030 (European Council, 2014). This also became the intended nationally determined contributions (INDCs) from Europe to the Paris negotiations late 2015. If one takes into account that half of this reduction had been achieved already as explained above, this agreement implies an annual $1.8 \%$ reduction only in emissions between 2014 and 2030, less than half the annual reduction needed to reach the long-term target that both the European Council and the European Parliament agreed to five 
years earlier. This is also more close to a third of what would be a reasonable European contribution to keep world temperature increase below $2^{\circ} \mathrm{C}$ (Rogelj et al., 2016). Hence, current EU leaders would seem to have ducked their responsibility, tacitly opting to leave most of the required efforts to future generations, by which time the task, according to IPCC analyses, will have become much harder (and the costs much higher).

\section{Is Europe doomed to a stalemate in transformation and growth policy?}

The climate challenge and the economic challenge that Europe is facing are intimately interrelated. ${ }^{3}$ Without growth, greenhouse gas emissions may continue to decline, although almost certainly not at the pace necessary for their elimination in the latter half of the present century. But employment would undoubtedly continue to suffer, too. A return to the type of growth that prevailed before the financial crisis, on the other hand, might be good for employment - in the short run at least - but certainly not for the climate, as emissions would continue at unsustainably high levels. Is there a way out of this dilemma?

As a start it may be noted that economic growth does not necessarily mean doing more of the same. It can also mean getting more out of a given level of resources by doing things in a smarter way than before or to develop other, and sustainable, resources - that is, by

3 The interrelated nature of these challenges, obvious at it may seem, has apparently not yet penetrated EU policy thinking to any great extent. For example, in the conclusions from the European Council meeting of October 2014 (European Council, 2014), climate change and stagnation are both highlighted, but there is no mention of their interrelated nature. 
innovation. There are important and sceptical voices with regard to the potential of future innovation, not the least Gordon (2012 \& 2016). But are there really reasons to believe that humankind is less capable of coming up with smart solutions than, say, fifty or hundred years ago? We believe the answer to this question is a clear ' $\mathrm{No}^{\prime}$. Smart solutions, or innovations, typically mean combining different sources of information, knowledge and other resources in a novel way, for which education is a great advantage (if not a must). Never have levels of education been as high as they are today. The same holds for our knowledge on how to mobilize the global resources to be used for new and better ways of doing things as evidenced e.g., by rapidly increasing share of R\&D expenditure in GDP globally (Figure 5).

(Figure 5 here)

Northern Europe, in particular, joins a club of high R\&D performers together with the United States, Japan and, not the least, Korea, which has doubled its investments in R\&D as percentage of GDP over the last two decades. A similarly rapid growth has occurred in China, which clearly aspires to join the countries on the R\&D frontier. In fact, albeit starting at a very low level two decades ago, China's share of R\&D in GDP is currently around 50\% above the world average. It is disquieting, therefore, that Southern and Eastern Europe continue to stay well below the world average, and that the difference has been increasing in recent years. Hence, these countries appear to fall behind not only economically but also with respect to science, technology innovation. This provides further evidence on the European divergence noted earlier. 
The main message in Gordons (2016) magnum opus is the decline of, what we here label, the marginal revenue of fundamental innovations (MRFI). These innovations - largely related to more efficient production and intensified use of energy - served as drivers for the period of high growth in total factor productivity (TFP) 1920 - 1970. There was also a shorter and less impressive period of TFP increases around the shift of the millennium (1994-2004) which, following Gordon, can be explained by the penetration of ICT in the economy. And, Gordon argues, the territory that once was conquered by the fundamental innovations during these periods cannot be conquered again.

In addition, and partly related, he points to a set of various countervailing factors - what he calls "headwinds" - contributing to a slower growth in income (or GDP per capita). He points specifically to demography (and an aging population), reduced scope for increasing the qualifications of the labour force (through investments in education), globalization, increasing inequality (which he identifies as arguably the most important 'headwind') and the large public and private debts that need to be reduced. The joint effect of these "headwinds" may well be to restrict future growth of GDP per capita in the United States to almost zero (Gordon, 2016, chapters 16-18).

However, and starting with the headwinds, what (perhaps) holds for the US does not necessarily hold for the world as a whole. For example, countries at a lower level of development can gain a lot by exploiting technologies already in place in technologically more advanced nations (Abramovitz, 1994). As pointed out above, GDP per capita in Europe is just 
two thirds of that in the US, so there should still be scope for catching up and hence for faster growth than in the US, especially in the in poorer EU Member States in Eastern Europe.

The issue of declining and aging populations, emphasized by Gordon, clearly represents a challenge for Europe ${ }^{4}$. In fact fertility rates have declined all over Europe for several decades (Figure 6) and presently only a handful of European countries are having fertility rates sufficient to ensure a constant population. This challenge is especially evident in Southern Europe as well as in some Eastern European countries (with Poland being the most important case).

(Figure 6 here)

It is interesting to observe that fertility rates in Europe actually increased during the period of inclusive growth, characterized by rapid catch-up by poorer member countries that preceded the financial crisis. However, in the years after the crisis struck fertility rates declined markedly, particularly in Southern Europe that received the biggest hit by the crisis and the Germaninspired austerity drive. Thus, as with several other challenges, the demographic challenge Europe is facing is something policy can influence, notably by breaking with austerity but also through other changes in the policy stance, for example by creating favourable conditions for families with children, and allowing for more integration of young, entrepreneurial job-seekers

\footnotetext{
${ }^{4}$ But not necessarily for the world as a whole, for example, an aging population is clearly not a problem in Africa, home to some of the fastest-growing countries in recent years. ${ }^{5}$ Similarly, average education levels are still low in most developing countries, so continuing investments in education there should be expected to bring large payoffs.
} 
from countries outside the EU, of which there appears to be an abundant supply. Hence, the growing anti-immigration sentiments in several European countries are both backward-looking and counter-productive.

Furthermore, while education levels are high in large parts of Europe, particularly in the North, average education levels in the South of Europe continue to lag substantially behind. Investing in education there, including the education of the current adult population who will continue to dominate the labour force for some time to come, may prove to be an essential element in a long-term policy for reviving the depressed economies in this part of Europe. ${ }^{5}$ Finally, while the distribution of income generally is much more equitable in Europe than in the US (Piketty, 2014), which according to recent research should be good for growth (Cingano, 2014), Southern Europe (together with the UK) represents to some extent an exception in this regard (Figure 7). Therefore, a policy aimed at reviving these economies may need to pay particular attention to the distributional aspects of economic development, which is of course quite the opposite of what the current austerity policies do.

(Figure 7 here)

Let us so, and not least important, return to the decline of what we above have labelled the Marginal Revenue of Fundamental Innovations (MRFI). It may be argued that the cognitive foundation - or paradigm - behind much of the scientific and innovative activities of mankind

\footnotetext{
${ }^{5}$ Similarly, average education levels are still low in most developing countries, so continuing investments in education there should be expected to bring large pay-offs.
} 
has been related to "mastering nature" rather than "adapting" to it. While there may be a declining MRFI along the old technological trajectory we are hopefully just in the beginning of learning on how to transform the economy within the Planetary Boundaries (cf. Steffen et al, 2015).

Not the least is this related to energy use. Gordon (2016, chapter 16$)$ frequently discusses the important role played by the growing input of energy - fossil fuels as well as (fossil based) electricity - as an explanation of the rapid increase of TFP during the period $1920-1970$. This is, however, not directly connected to climate change. Still it adds to the headwinds. To maintain existing TFP levels for the future - and still more to increase productivity - all this energy input has to be substituted in one way or another by other and sustainable/renewable solutions. This will require huge innovations.

In theory, at least, this can be done; for the USA as well as for the rest of the world. Although the inflow of solar energy to Earth is every hour approximately 11 times as large as mankind uses in a whole year (Sandén, 2008) there will be a strong need to economize with energy in the transformation towards a sustainable trajectory (Moriarty \& Honnery, 2016). In the language of the International Energy agency this will include innovations all over society to avoid, as well as to improve and substitute energy related activities (IEA, 2014).

In sum we don't think the continuing stagnation in Europe can be explained mainly by less scope for innovation, or indeed "headwinds" of the type emphasized by Gordon. It also has to do with policy and governance to allow Europe to enter upon a path transforming our economies towards sustainability, the topic to which we now turn. 


\section{The governance challenge facing Europe}

In this section, we examine the governance challenge faced by Europe with regard to developing the necessary policies for economic recovery and transformation and confronting issues related to climate change and sustainability.

A first issue has to do with the increasingly global nature of the problems confronting governments, requiring internationally coordinated, multilateral efforts that are hard to bring about, as evidenced by the failure so far to come up with a comprehensive international agreement on how to deal climate change. Nevertheless, as pointed out by Laestadius (2015) and Schmitz and Lema (2015), there may be possibilities for international cooperation affecting climate change even in the absence of an effective global treaty, such as alliances of likeminded countries (with Europe taking the lead) pioneering new solutions and encouraging others to follow.

Secondly, not only are the problems to be confronted today large-scale, but they are also more likely to cross-cut organisational boundaries, particularly within governments (Bauer et al., 2012) and tend to interact in an increasingly complex manner. Energy policy, for instance, must give careful consideration to a range of issues including security (Geels, 2015). Therefore, effective policies for transforming the economy towards sustainability may require the development of new forms of governance, characterized by a holistic perspective and by close coordination between different parts of government.

A third issue relates to the increasing involvement of non-government actors, not least in Europe (Biermann, 2007; Biermann \& Pattberg, 2008; Biermann \& Gupta, 2011; Bauer et al., 
2012). However, while making governance more complex, the involvement of nongovernmental actors may also introduce a much needed new dynamics in policy-making, as evidenced, for example, by the German Energiewende (Box 1, see also Lauber and Jacobsson 2015 ) and the Norwegian policy on electric cars (Box 2).

Fourth, there is a heightened sensitivity to risk and uncertainty (Biermann, 2007). The fundamentally uncertain nature of technological advance means that policies for transformation should place the emphasis on pursuing a broad portfolio of different energy technologies and on not getting locked into a specific path of development that at one point may appear more cost-effective or promising. The German "Energiewende" (see Box 1) is an excellent example of how this can be achieved.

\section{Box 1 Germany's transition to sustainable electricity production - the Energiewende}

One of the most remarkable achievements of any European country when it comes to transforming its economy in a sustainable direction is provided by Germany. In just fifteen years, from 1998 to 201 5, the share of renewables in German energy consumption increased from less than five to over 30 per cent (Figure 8). The German "Energiewende" - literally energy transition - had its origins in the environmental and anti-nuclear movements of the 1970s and 1980s (in particular the Green party). Renewable energy was seen as critical for phasing out nuclear generators, and the first national scheme requiring utilities to purchase renewable power from private sources at a fixed rate (so-called 'feed-in tariff') was adopted by parliament in 1990. The coalition between Social Democrats and Greens that came to power in 1998 
continued and expanded these policies. The feed-in tariff were set at different levels for different technologies (e.g. solar, bio, on-shore wind, off-shore wind etc.) depending on how far these had come with respect to being commercially viable. It is thus an example of a policy supporting technological development on a broad front, allowing different technologies time to deliver on their promise, thus avoiding premature lock-in to a specific technology at a too early stage.

(Figure 8 here)

The process acquired substantial momentum after the turn of the millennium, and growth has been especially rapid in recent years. A substantial German capital-goods industry also developed and costs declined as envisaged. However, as a result of its success, the policy has also become more controversial. For example, it has come under fire from electricity utilities (with huge sunk costs in coal-based plants) and politicians from coal-producing regions. The policy's support for a broad range of renewables, rather than concentrating on the currently most cost-effective (and hence most mature) technologies, has also been repeatedly criticized for being too costly. The entry of China in some segments of renewable energy technology, which to some extent has come at the expense of jobs in Europe, has also weakened the popularity of the policy in some circles.

Source: Lauber and Jacobsson (2015) 
A fifth factor adding to the governance challenges facing the EU is the growing number and diversity of Member States. Now, with 28 Member States, EU countries have become quite different in terms of economic, industrial and institutional characteristics, and policies based on the philosophy of 'one size fits all' appear less appropriate than ever.

Lastly, and again a factor specific to the governance challenge faced by the EU, is the fact that the scale of resources at the disposal of the EU is in most cases very limited compared with those allocated by national governments (Begg, 2015). Hence, the ability to influence and coordinate national governments becomes essential.

The declining trust in (and diminishing popular support for) European institutions (Begg, 2015) indicate that the failure of EU politicians in dealing effectively with the challenges that Europe faces is now coming back to haunt the entire European project. This clearly underscores the need for a new policy stance. As pointed out above, simply pumping up demand would quickly come into conflict with climate concerns and hence not be sustainable. Therefore a policy aiming at a new form of 'green growth in Europe in order to increase employment and welfare must simultaneously speed up the transformation to a sustainable economy. The challenge with this transformation is shortly analysed in box 3 below.

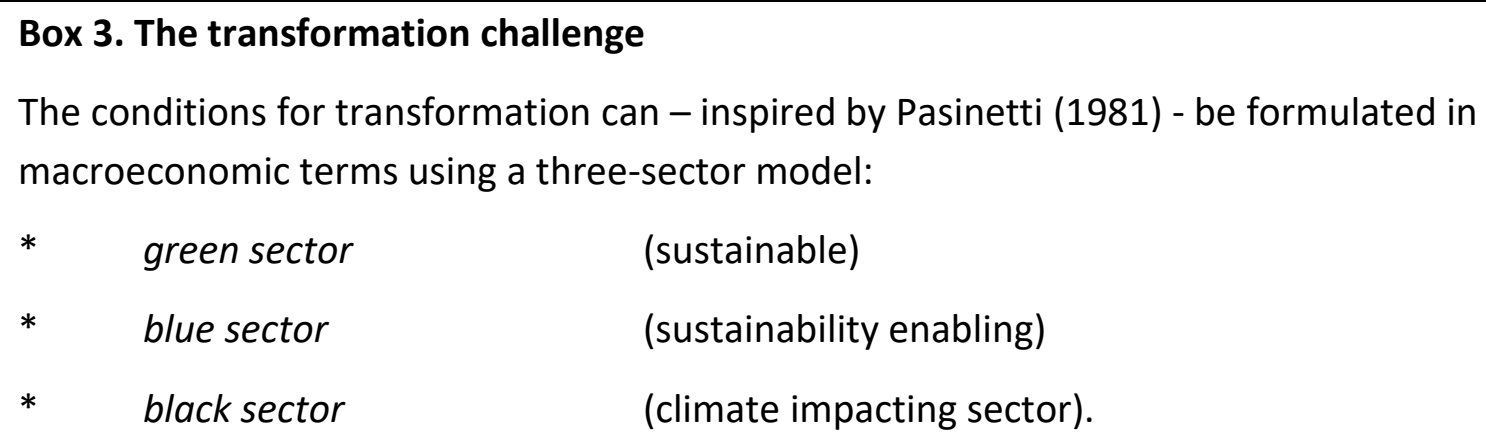


The green sector consists of non- $\mathrm{CO}_{2}$ generating activities (the service sectors, ecologically produced food and other "green artefacts"), investments in human and cultural capital, and exports of non- $\mathrm{CO}_{2}$-emitting goods and services. Bio-based products from sustainable forestry and agriculture also belong to this category.

The blue sector consists of activities which in themselves may be polluting but which in their use will contribute to a reduction of $\mathrm{CO}_{2}$ emissions. On the consumption side this includes energy-saving and long-lasting artefacts (e.g. heat pumps). Among blue investments we may identify railway tracks as well as wind-power systems and investments in energy efficiency. To the black sector we allocate all activities, consumption of - and investment in - products, systems and services that generate $\mathrm{CO}_{2}$ emissions.

The policy challenge from a macroeconomic point of view is not to unconditionally "pump up demand" in general to increase employment but, with help from the blue sector, to rapidly transform demand away from the black sector towards the green. It is not enough to reduce the relative size of the black sector; it must be reduced in absolute terms, eventually to a negligible level.

This transformation of activities may generate "green growth" if the green and blue sectors expand more than the decline of the black. Whether there is a creation of net employment depends on the labour absorption capacity of the growing green and blue activities relative to the declining black.

This requires highly selective policies all over the economy at the expense of general macroeconomic policies.

The best way to achieve this, we argue, is to target innovation, diffusion of new technology and, not the least, transformative investments in areas such as energy supply and distribution, increased energy efficiency, public transport, infrastructure for cars driven by electricity and fuel cells, and so on. Many of these investments, in the energy sector for example, would be necessary anyway (ECF, 2013) but undertaking them sooner rather than later (and using reduced GHG emissions as a yardstick in the selection process) may accelerate the 
transformation while at the same time reviving growth. As pointed out above, such a policy stance has to take into account the fact that the economies of Europe are very different, so there is no point in just mimicking the same policy, whether patterned on German experience or that of some other country, everywhere. Rather, what needs to be done is to identify the factors that prevent the various economies from growing and then addressing these factors head on.

While such transformative investments are needed in all member countries, it is natural to place the emphasis on those countries that have further to go with respect to achieving sustainability. As Figure 9 shows, the countries most in need of transforming their economies in the direction of sustainability are poorer member countries (which are also in general the ones most adversely affected by the current stagnation). Thus, a programme for transformative investment based on these principles would not only be good for climate change and economic growth generally, but also deliver growth where it is most needed, thereby contributing to improved social cohesion in the Union as a whole.

(Figure 9 here)

Recently, the governing bodies of the EU, in particular the European Commission and the European Central Bank, have started to devote more attention to the need to get Europe out of the present slump by increasing investments (European Commission, 2014) and adopting a more expansionary monetary policy. However, although these initiatives are surely welcome, 
they will do little to stimulate the much needed European transformation towards sustainable growth. ${ }^{6}$

The crucial question for policy, therefore, must be how to get the European economy out of its present depressed state and simultaneously mobilize the European population in a collective innovation journey in the direction of a sustainable economy and society. Innovation is not, as sometimes presented, primarily about creating new ideas that may (or may not) have profound effects sometime in the distant future. Rather it is about trying out promising new solutions and ways of doing things, learning from the experience and on this basis improving the technologies in question. Therefore, a good innovation policy is one that also promotes diffusion, use, learning and continuous improvement.

To achieve this transformation, creating demand for innovative new solutions may be essential. In fact, as the Norwegian example of supporting the demand for electric cars shows ( Figenbaum and Kolbenstvedt 2013, Fagerberg, Laestadius and Martin 2016) , demand-oriented policies can lead to surprisingly large changes during a relatively short time span. This matters

6 For example, in a recent presentation of the EU investment plan, Vice-President Jyrki Katainen did not once mention climate change or sustainability (see "Vice-President Jyrki Katainen explains the EU investment plan", http://ec.europa.eu/priorities/jobs-growth-investment/plan/index_en.htm, accessed on 22 January 2015). 
because, in order to minimize the adverse consequence of climate change, the transformation process has to occur rather rapidly.

\section{Conclusions}

Europe (like many parts of the world but perhaps even more so) is confronted by an intimidating triple challenge comprising economic stagnation, climate change, and a governance crisis. This paper demonstrates how these three challenges are closely interrelated. In particular, a return to economic growth cannot come at the expense of greater risk of irreversible climate change. Instead, what is required is a fundamental transformation of the economy to a new 'green' trajectory based on rapidly diminishing emission of greenhouse gases.

Boosting Europe's economy and its transition to a sustainable 'green' economy through transformative investments should be seen as a core element of European policy for innovation and growth (Mazzucato and Perez, 2015). Innovation is not primarily about scientific breakthroughs, although these are often very important, but more about continuous experimentation, learning, gradual improvements, cost reductions and increased performance of technologies that are already on the table (Mathews, 2014). Policy makers can exert great influence on innovative activities by emphasizing the most pressing challenges or problems that need to be addressed. This type of innovation policy, which provides a sense of direction to the collective innovation journey and rallies potential contributors behind it, would be relevant for a wide range of activities essential for the transition to a sustainable economy, such as energy 
production, distribution and use, and also transport and construction. In order to be effective such a policy may have to link and coordinate different policy arenas (energy, transport, regional development, research, innovation etc.). Thus, sustainable growth requires more than technological innovation; new forms of governance are also required.

The dominant policy approach to dealing with climate change in Europe up to now has tended to focus on getting "the prices right", with the Emissions Trading Scheme (ETS) as the central instrument. Yet this has proved far from successful. ${ }^{7}$ The reason is not that there is something inherently wrong with getting "the prices right" but rather that getting political support for the necessary adjustments in prices (through increasing taxes or cutting quotas or in other ways) has proved very difficult.

\section{Box 6: Getting the prices right}

Although European taxation systems differ a lot they all have in common that they are far from getting the prices right to provide incentives for economic actors to change their behaviour.

The conventional wisdom as regards taxation is not valid in a situation when you rapidly have to decarbonize parallel to stimulating non fossil activities. Investments in the sustainable

7 The ETS (see Begg, 2015) has completely failed in terms of creating a price-level for GHG emissions that would stimulate a transition towards increased sustainability. As argued by Laestadius (2015), $\mathrm{CO}_{2}$ prices will have to increase to around €40/ton or more in order to contribute to this transformation. Yet throughout 2014 they only sporadically exceeded $€ 7.50 /$ ton. 
technologies of tomorrow - and in those which are already available - demand significant changes in price relations. And they have to be delivered with credibility by the political system.

Even if the dramatic tax changes - and related regulations - intended to promote decarbonization cannot be introduced from one day to another they can be declared in the form of tax paths to come, thus allowing actors to adapt. Such taxation paths may also be a necessary means to get success in the necessary taxation of international bunker fuels.

Moreover, timing is crucial here. Arguably, acquiring the necessary momentum in the transformation process is critically dependent on mobilizing broad segments of society through advocating and experimenting with new solutions. It is very notable that successful transformation policies, such as the German Energiewende and the Norwegian programme for electric cars, were not created through top-down initiatives by political leaders, but by pressure from green movements and environmental activists, which gradually received increasing support for these policies as they acquired momentum.

Energiewende and the Norwegian electric car programme are examples of what economists often call "second best" policies, reserving the term "first best" for "getting the prices right". Yet it is fallacious (even from an economic theory point of view) to criticize these policies on the argument that they are more expensive than "first best" policies when it is quite obviously illusory to assume that the latter will deliver the goods in time. Moreover, if combatting climate change requires a considerable amount of innovation, as almost everybody seems to agree, 
then it is not only the costs of particular policies here and now that matter but also the effects on innovation. In this respect, a policy such as Energiewende is an inspiring example because it creates opportunities for experimenting, learning and innovating with a broad range of energy technologies, instead of becoming locked in to what observers at a certain point might see as the most 'cost-effective' approach. In fact, incorrect assessments of this kind can have considerable costs. For example, a century ago, electric cars were more common than today when measured in terms of their share of the total car stock. That technological trajectory was then rejected in favour of the seemingly more cost-effective internal combustion engine driven by fossil fuels. But with hindsight, that assessment would now seem highly questionable because it did not take into account the detrimental consequences of petrol-driven cars for the climate and the economic costs this entails.

As pointed out earlier, other parts of the world are also facing varying forms of the triple challenge. Given the global character of the problem, and the many actors involved at different levels all round the world who may have a say in what happens, the ability to influence actors in other countries becomes of central importance. One key way to achieve this, and one for which Europe seems eminently well placed, would be to lead by example, providing solutions for how the climate challenge can be effectively dealt with. Taking the lead may, of course, incur significant costs. Nevertheless, the cost structure is far from obvious, doing nothing will undoubtedly have a major impact in the years ahead in many areas of life. By taking the lead in addressing the triple challenge, Europe may not only attract followers, thereby ensuring that climate change is kept within manageable bounds; it may also lead to considerable benefits in the longer term in the form of strengthened industrial competitiveness, enhanced exports and 
new jobs ${ }^{8}$. Moreover, addressing the triple challenge may provide Europe and its citizens with a new sense of purpose, revitalizing the EU, 'the European project' and Europe's role in the world over the decades to come.

8 Mathews (2014) argues that China's leadership is well aware of this possibility, and that China is already on the path to becoming the global leader in green technologies. 


\section{References}

Abramovitz, M. (1994). 'Catch-up and convergence in the post-war growth boom and after', in W.J. Baumol, R.R. Nelson \& E.N. Wolf (eds.), Convergence of Productivity - Cross-National Studies and Historical Evidence, Oxford: Oxford University Press, 86-125.

Bauer, A., Feichtinger, J. and Steurer, R. (2012). 'The governance of climate change adaptation in 10 OECD countries: challenges and approaches', Journal of Environmental Policy \& Planning, 14: $279-304$.

Begg, I. (2015) EU Policy and Governance: Part of the Problem or Part of the Solution? In Fagerberg, J., S. Laestadius and B. R. Martin (2015).

Biermann, F. (2007). 'Earth system governance as a crosscutting theme of global change research', Global Environmental Change, 17: 326-337.

Biermann, F. and Gupta, A. (2011). 'Accountability and legitimacy in earth system governance: a research framework', Ecological Economics, 70: 1856-1864.

Biermann, F. and Pattberg, P. (2008). 'Global environmental governance: taking stock, moving forward', Annual Review of Environmental Resources, 33: 277-294.

BP (2016a). BP Statistical Review of World Energy, June 2016 http://www.bp.com/en/global/corporate/energy-economics/statistical-review-of-worldenergy.html 
BP (2016b). BP Statistical Review of World Energy, June 2016, Carbon Dioxide Emissions http://www.bp.com/en/global/corporate/energy-economics/statistical-review-of-worldenergy.html

Cingano, F. (2014). 'Trends in income inequality and its impact on economic growth', OECD Social, Employment and Migration Working Papers, No. 163, Paris: OECD Publishing (downloaded from http://dx.doi.org/10.1787/5jxrincwxv6j-en on 7 January 2015).

ECF (2013), 'From Roadmaps to Reality - A Framework for Power Sector Decarbonisation in Europe', Brussels: European Climate Foundation.

European Commission (2014), 'An Investment Plan for Europe', Brussels: European Commission (downloaded from http://ec.europa.eu/priorities/jobs-growth-investment/plan/index en.htm on 7 January 2015 ).

European Council (2014), 'Conclusions from the European Council 23 and 24 October 2014', EUCO 169/14, Brussels: European Council.

(http://register.consilium.europa.eu/doc/srv?|=EN\&f=ST\%20169\%202014\%20INIT )

Fagerberg, J., S. Laestadius and B. R. Martin (2015) The Triple Challenge for Europe: Economic Development, Climate Change and Governance, Oxford University Press, forthcoming.

Fagerberg, J. and B. Verspagen (2015) One Europe or Several? Causes and Consequences of the European Stagnation, in Fagerberg, J., S. Laestadius and B. R. Martin (2015).

Figenbaum, E, and M. Kolbenstvedt (2013) Electromobility in Norway - experiences and opportunities with Electric Vehicles, Report 1281/2013, The Institute of Transport Economics , 
https://www.toi.no/publikasjoner/elektromobilitet-i-norge-erfaringer-og-muligheter-medelkjoretoy-article32103-8.html

Geels, F. W. (2015) The arduous transition to low-carbon energy: A multi-level analysis of renewable electricity niches and resilient regimes, in Fagerberg, J., S. Laestadius and B. R. Martin (2015).

GMDAC (2016) IOM Global Migration Data Analysis Centre, http://iomgmdac.org

Gordon, R. (2012). 'Is US Economic Growth Over? Faltering Innovation Confronts The Six Headwinds', Working Paper 18315. Cambridge, Mass.: NBER.

Gordon, R. (2016) The Rise and Fall of American Growth - the U.S. Standard of Living Since the Civil War, Princeton \& Oxford: Princeton University Press.

IEA (2014) Energy Technology Perspectives - Harnessing Electricity's Potential, Paris: OECD, International Energy Agency.

IEA (2015) Global EV Outlook 2015, http://www.iea.org/evi/Global-EV-Outlook-2015-

Update 2page.pdf, accessed on March 12, 2015.

IEA (2015b) Energy and Climate Change - World Energy Outlook Special Report, Paris: OECE/IEA.

IPCC (2012), 'Managing the Risks of Extreme Events and Disasters to Advance Climate Change Adaption', Cambridge: Cambridge University Press.

IPCC (2013a), 'Climate Change 2013 - Mitigation of Climate Change', Cambridge: Cambridge University Press. 
IPCC (2013b), 'Climate Change 2013 - the Physical Science Basis', Cambridge: Cambridge University Press.

IPCC (2014), 'Climate Change 2014 - Mitigation of Climate Change' (WGIII contribution to AR5). (www.mitigation2014.org).

Laestadius, S. (2015) Transition paths: assessing conditions and alternatives, in Fagerberg, J., S. Laestadius and B. R. Martin (2015).

Landesmann, M. A. (2015) The new North-South Divide in Europe - Can the European Convergence Model be Resuscitated? In Fagerberg, J., S. Laestadius and B. R. Martin (2015).

Lauber, V. and S. Jacobsson (2015) Lessons from Germany's Energiewende, in Fagerberg, J., S. Laestadius and B. R. Martin (2015).

Mathews, J. (2014) Greening of Capitalism: How Asia Is Driving the Next Great Transformation, Stanford: Stanford University Press.

Mazzucato, M. and C. Perez (2015) Innovation as Growth Policy: the Challenge for Europe, in Fagerberg, J., S. Laestadius and B. R. Martin (2015).

Moriarty, P. \& Honnery, D. (2016) 'Can renewable energy power the future?', Energy Policy 93, p 3-7.

Mowery, D.C., R.R. Nelson and B.R. Martin (2010). 'Technology Policy and Global Warming: Why New Policy Models are Needed (Or Why Putting New Wine in Old Bottles Won't Work)', Research Policy, 39, pp.1011-1023. 
Nordhaus, W. (2013). The Climate Casino - Risk, Uncertainty and Economics for a Warming World, New Haven \& London: Yale University Press.

Pasinetti, Luigi (1981) Structural Change and Economic Growth: a theoretical essay on the dynamics of the wealth of nations, Cambridge: Cambridge U.P.

Piketty, T. (2014). Capital in the Twenty-First Century. Cambridge, Mass: The Belknap Press.

Rogelj, J. et al., (2016) 'Paris Agreement climate proposals need a boost to keep warming well below $2^{\circ} \mathrm{C}^{\prime}$, Nature $534,631-639$.

Schmitz, H. and R. Lema (2015) The Global Green Economy: Competition or Cooperation between Europe and China? In Fagerberg, J., S. Laestadius and B. R. Martin (2015).

Reilly et al, (2015) Energy and Climate Outlook - Perspectives from 2015, MT Joint Program on the Science and Policy of Global Change, Cambridge, Mass: MIT.

Sandén, B. (2008) "Solar solution: the next industrial revolution", Materials Today, 11(2): 22-24.

Smil, V. (2010), Energy Transitions - History, Requirements Prospects, Santa Barbara, California: Praeger.

Steffen, W. et al, (2015). Planetary boundaries: Guiding human development on a changing planet, Sciencexpress, Jan 15, p 1-15, http://science.sciencemag.org/content/early/recent World Bank (2012), 'Turn Down the Heat - Why a $4^{\circ} \mathrm{C}$ Warmer World Must be Avoided', Washington, D.C.: World Bank.

World Bank (2013), 'Turn Down the Heat - Climate Extremes, Regional Impact, and the Case for Resilience', Washington, D.C.: World Bank. 
Figure 1. Europe: GDP per capita relative to the US, constant US\$ (PPP), 1995-2015

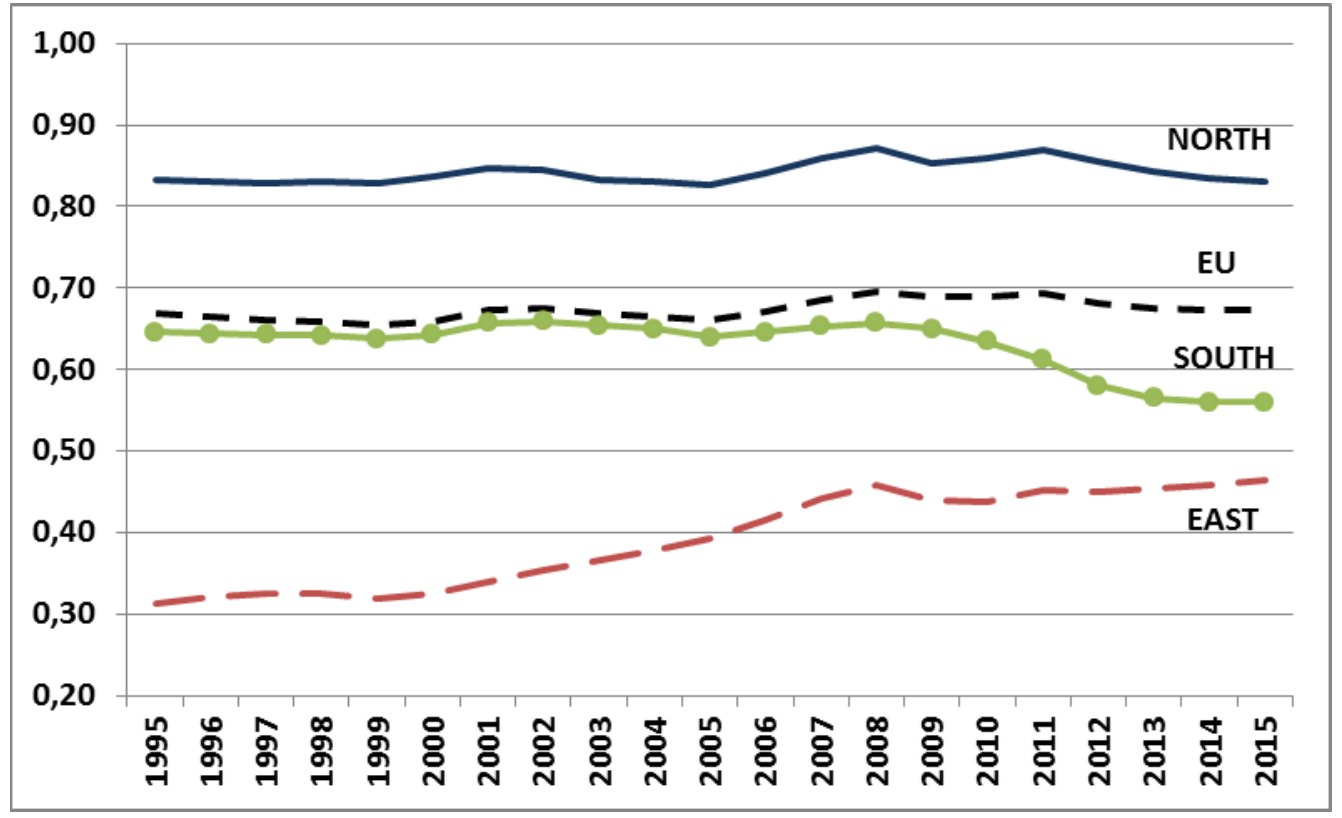

Note. Authors' calculations on GDP per capita, in constant US\$ (PPP-adjusted) at 2011 price levels, based on data from the World Bank (http://data.worldbank.org/indicator/NY.GDP.PCAP.PP.KD), accessed on 1.10.2016. EU includes all member countries, NORTH consists of Denmark, Sweden, Finland, Germany, Netherlands and Austria; SOUTH comprises Greece, Italy, Portugal and Spain; while EAST includes the 11 previously socialist countries in the East of Europe (that became members after the collapse of the Soviet Union).

Figure 2. Europe: Youth Unemployment (20-24 years)

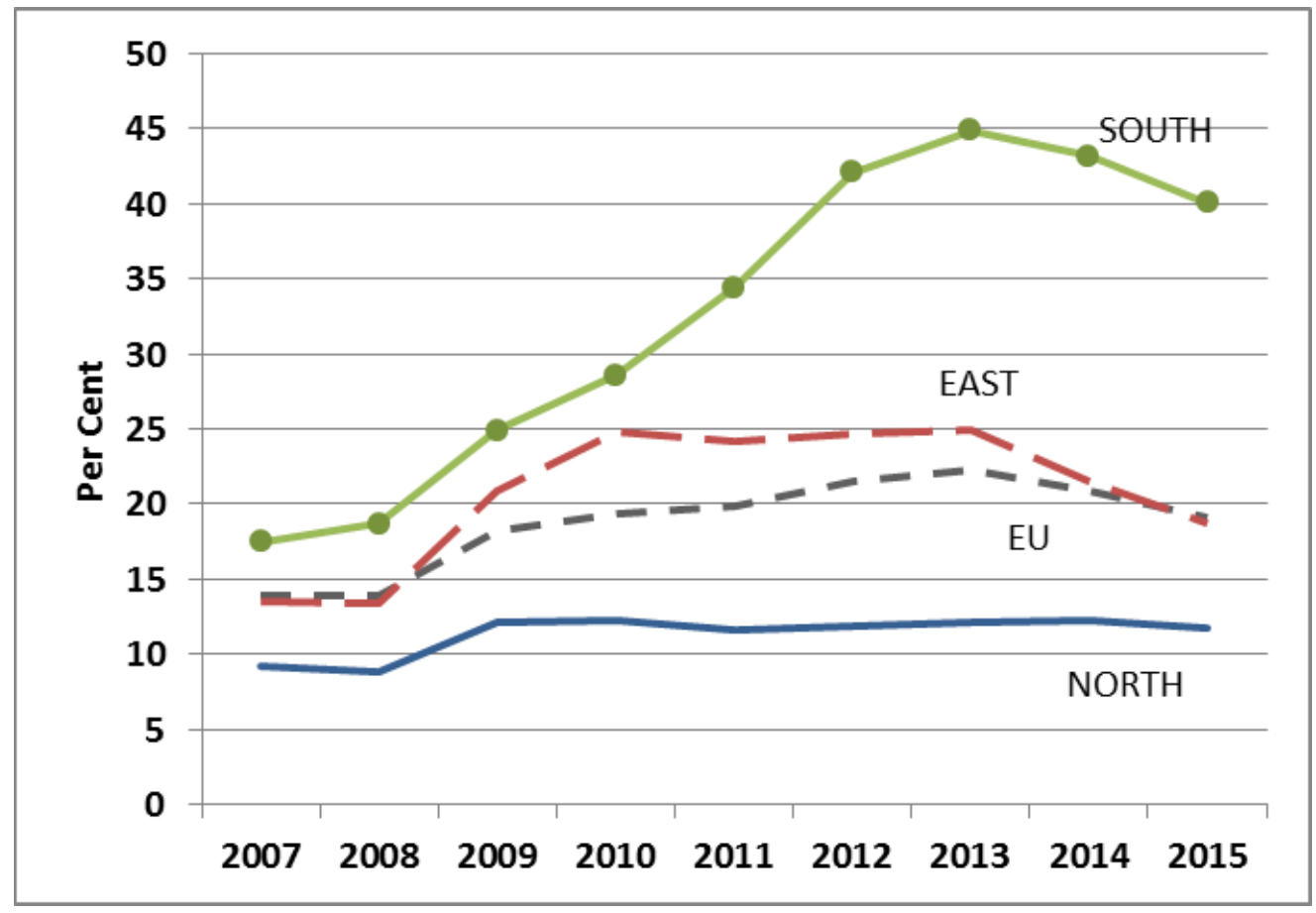


Note. Authors' calculations based on data from Eurostat (http://appsso.eurostat.ec.europa.eu/ (yth_empl_090)), accessed on 1.10.2016. For definitions of country groups see note to Figure 1.

Figure 3. GHG emissions, EU28, 1990-2014

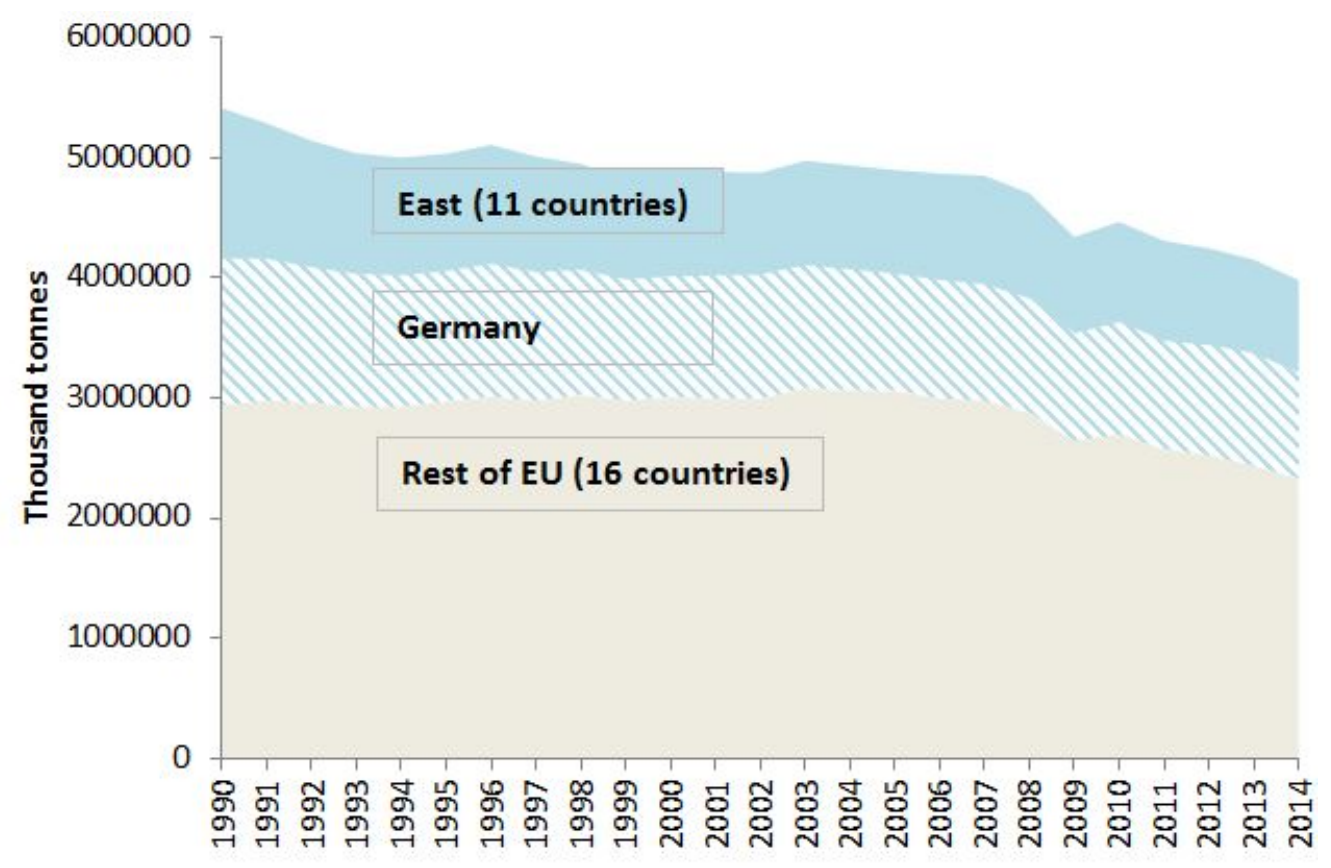

Note: Authors' calculations based on data from Eurostat (http://appsso.eurostat.ec.europa.eu/ [env_air_gge], accessed on 1.10 .2016 
Figure 4. GDP and GHG emissions, EU28, 1995-2014

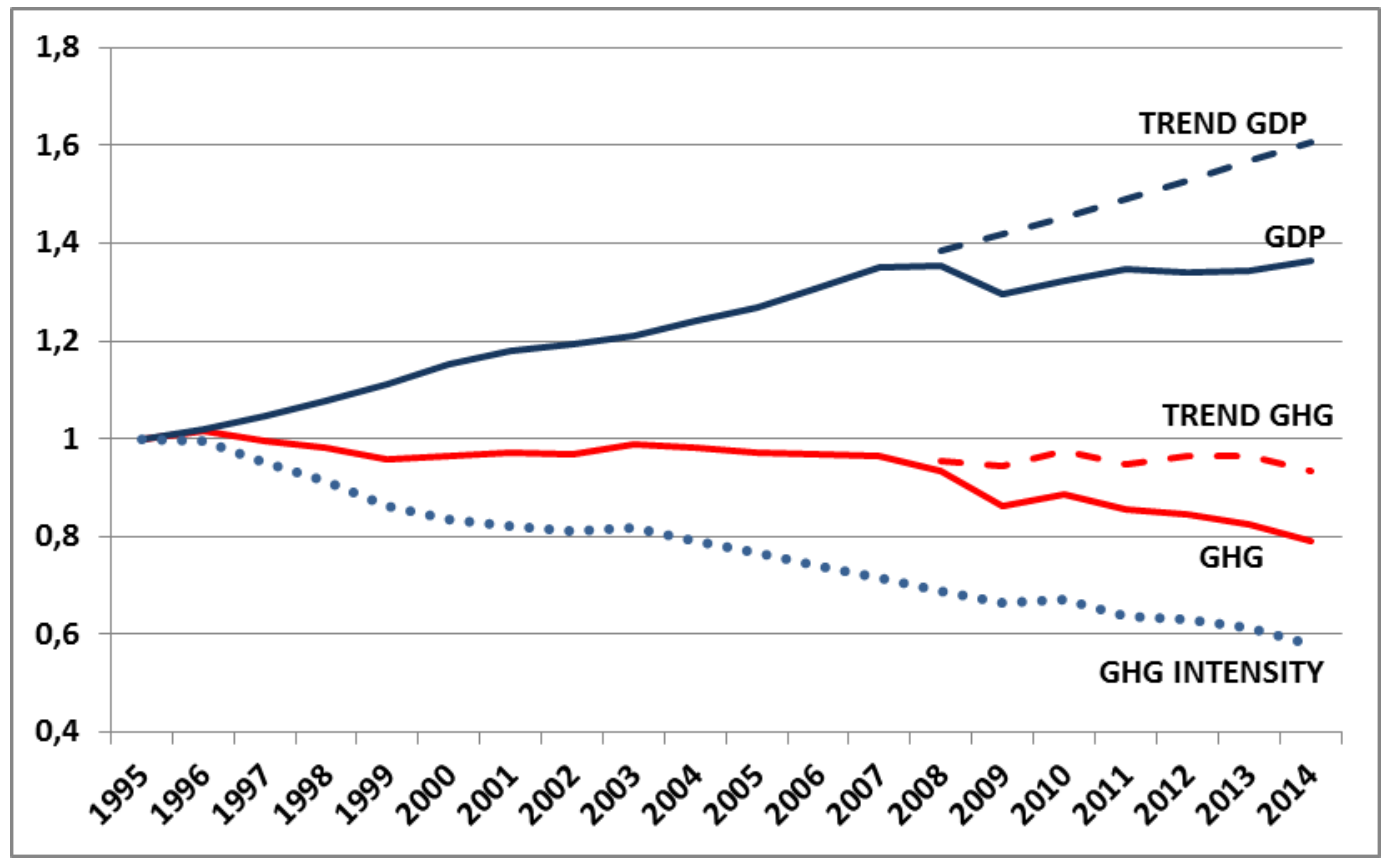

Note: Authors' calculations based on data from Eurostat (http://appsso.eurostat.ec.europa.eu/[nama_10_gdp] and [env_air_gge], accessed on 1.10.2016). Trend-GDP is a continuation of the 1995-2007 trend for GDP, while Trend-GHG is what the emissions would have been in that case (with actual GHG intensity).

Figure 5. R\&D as share of GDP, 1996-2014

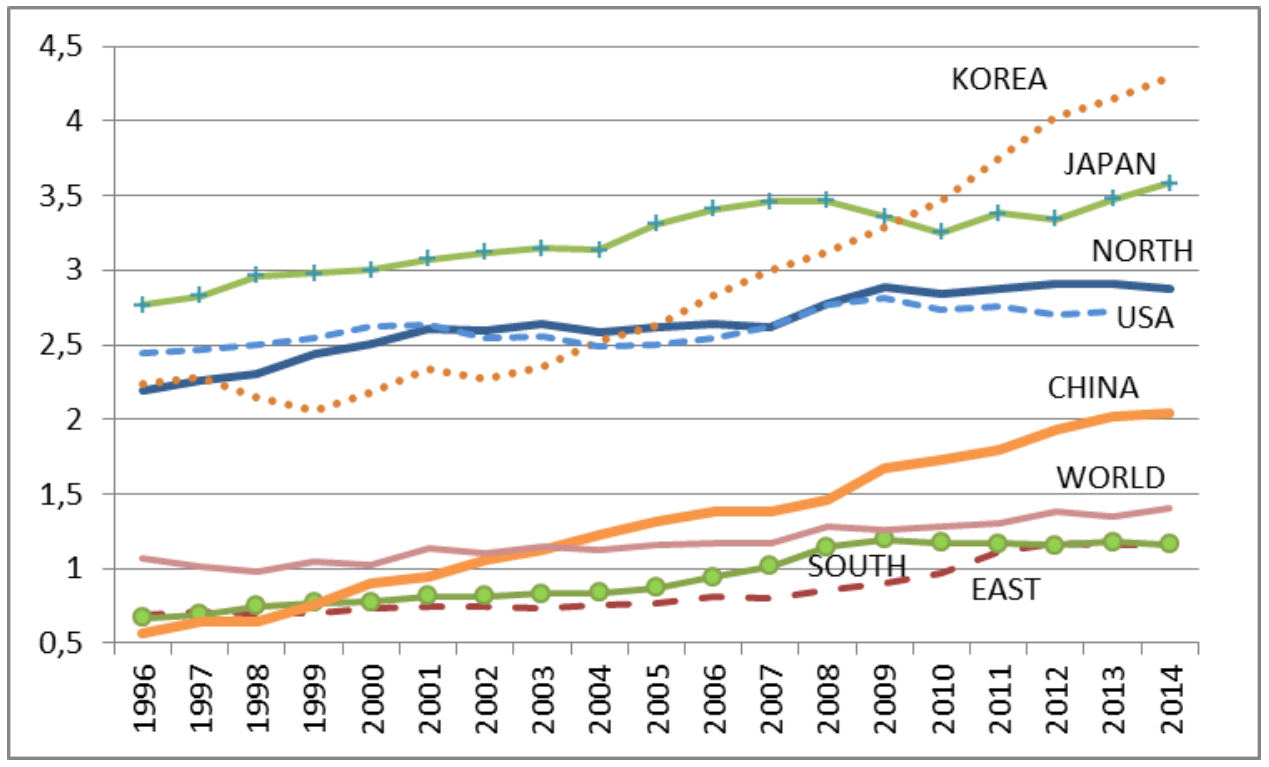


Note: Authors' calculations based on data from data from UNESCO ( http://data.uis.unesco.org/), accessed on 1.10.2016. "WORLD" is the average value for the 64 countries for which reasonably comprehensive data exist. NORTH, EAST and SOUTH are groups of European countries (for definitions see note to Figure 1).

Figure 6. Europe: Fertility-rates (live births per woman), 1970-2014

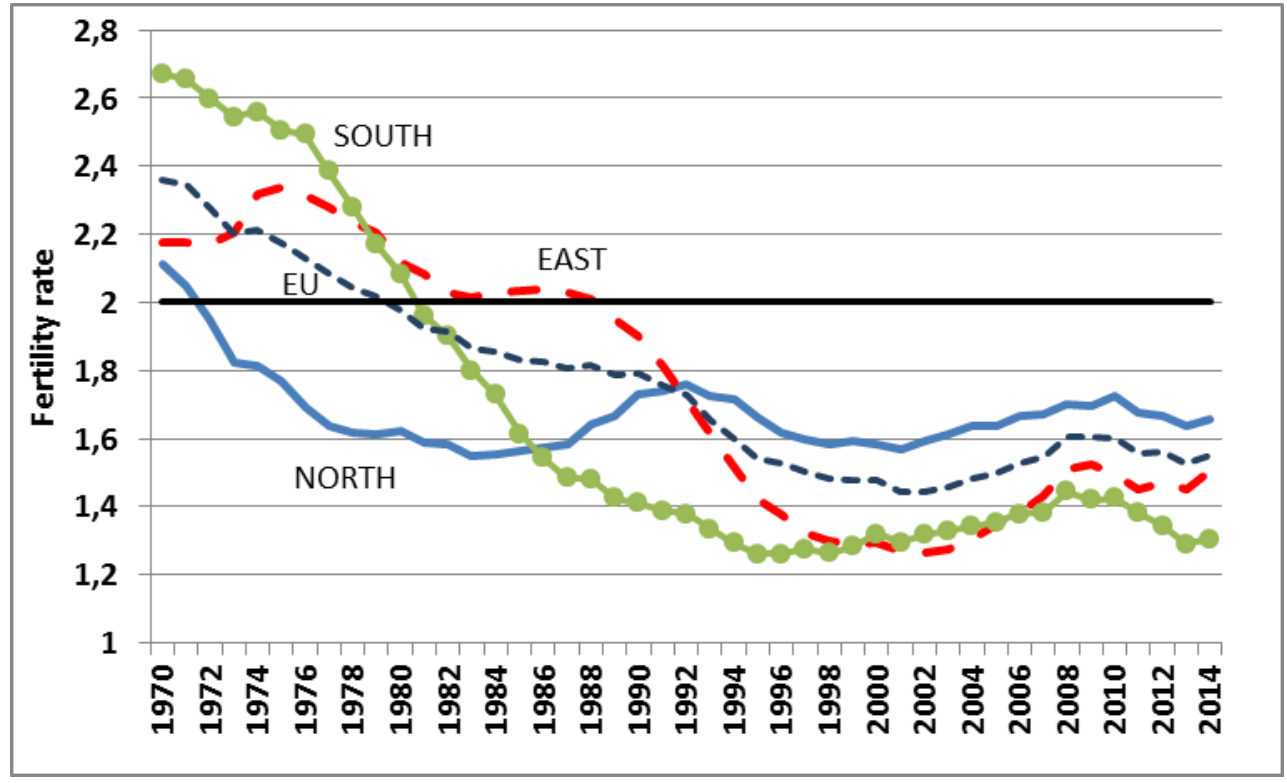

Note: Authors' calculations based on data from Eurostat

(http://appsso.eurostat.ec.europa.eu/[demo frate]) , accessed on 1.10.2016.

\section{(alternative version of Figure 6)}

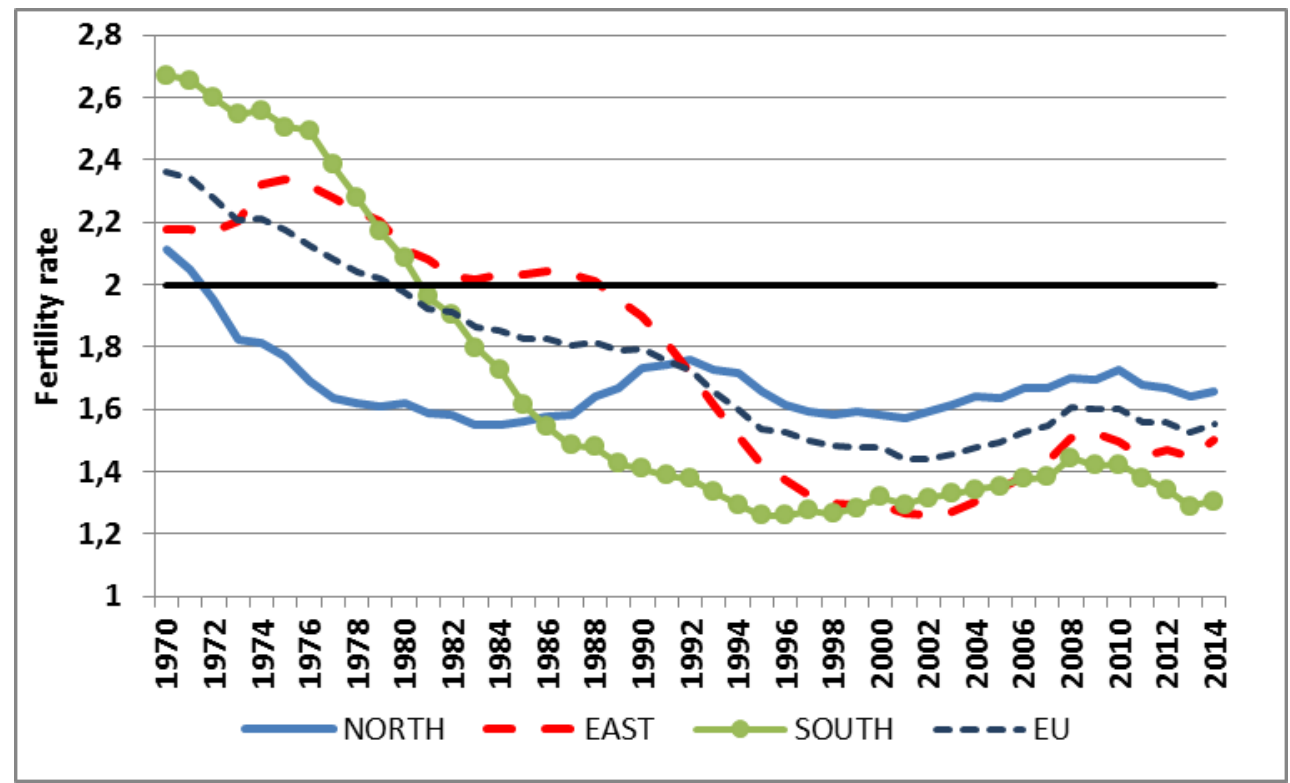


Figure 7. Inequality (gini-coeffecient), total population, 2013

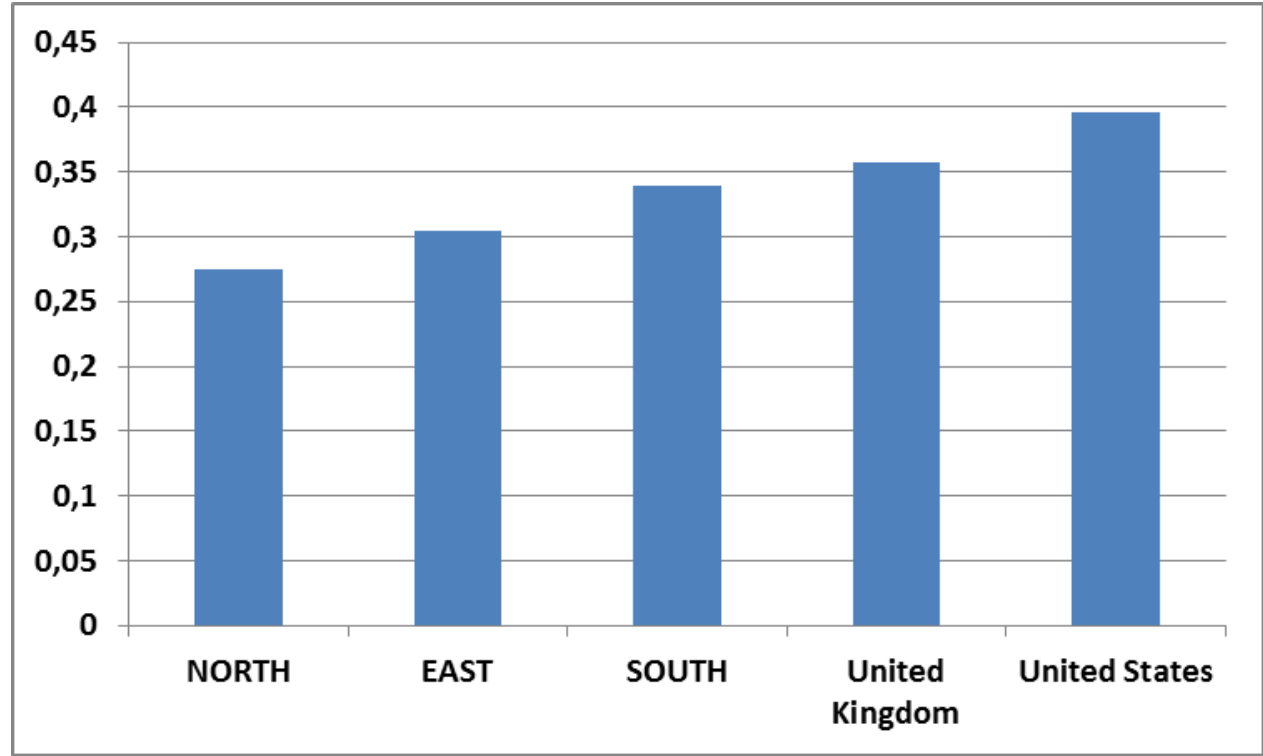

Note: Authors' calculations based on data from OECD Income Distribution Database (IDD),

http://www.oecd.org/social/income-distribution-database.htm, accessed on 1.10.2016. The coefficient is for disposable income (post taxes and transfers). 
Figure 8. Renewables as a share of total German electricity consumption, 1990-2015

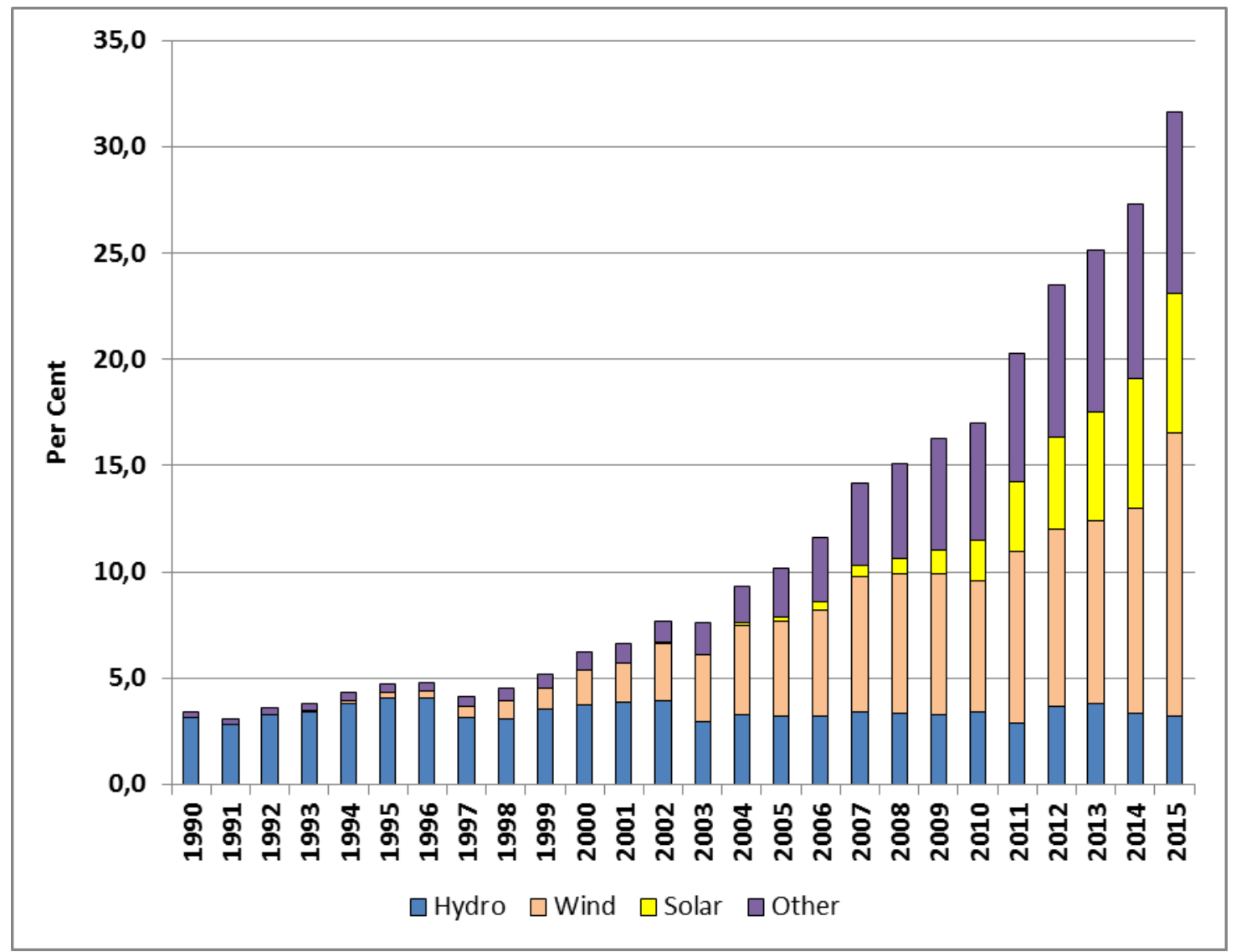

Note: Authors' calculations based on data from Bundesminister für Wirtschaft und Energie,

(http://www.bmwi.de/DE/Themen/Energie/Energiedaten-und-analysen/Energiedaten/gesamtausgabe), accessed on 1.10 .2016 
Figure 9. GHG intensity and GDP per capita, EU28, 2014

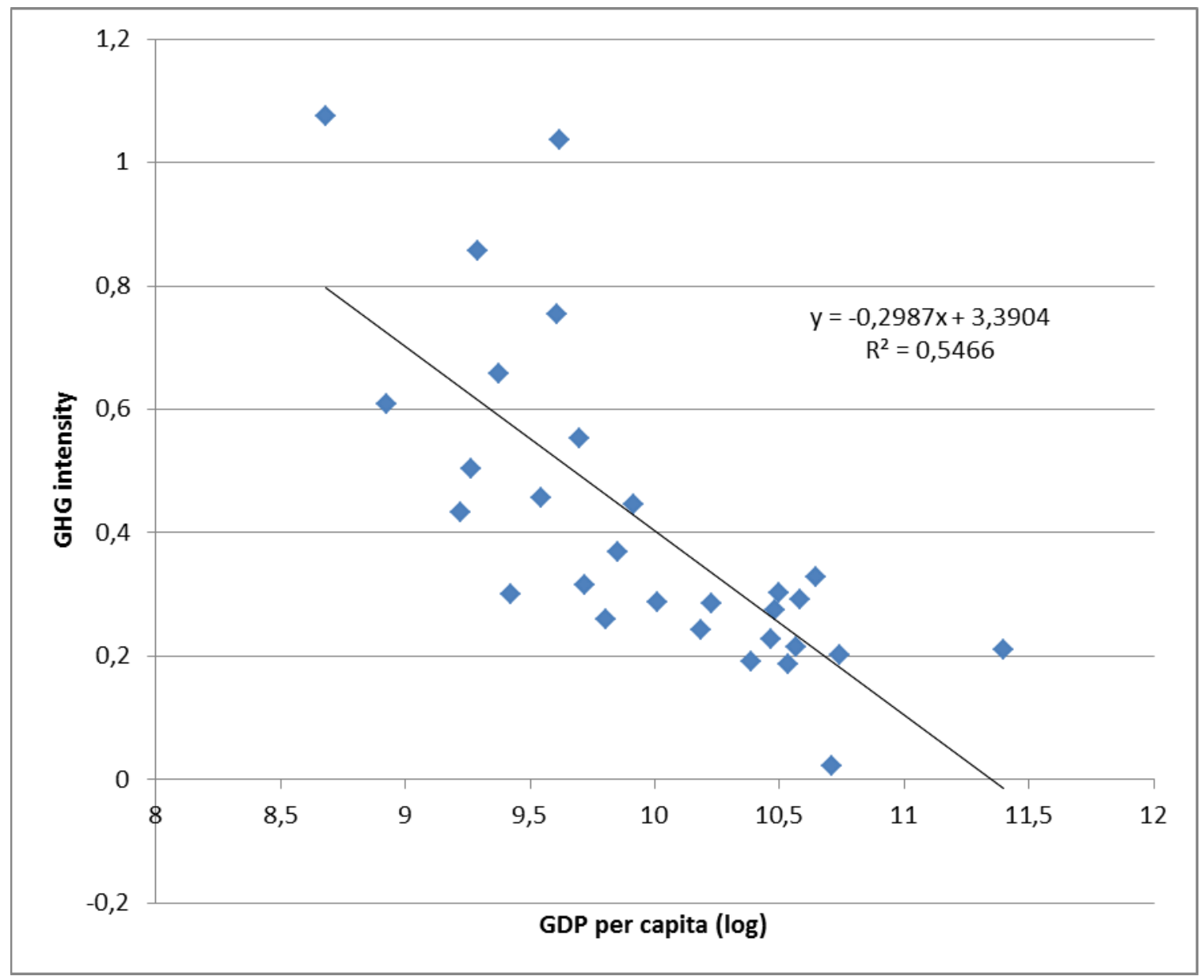

Note: Authors' calculations based on data from Eurostat (http://appsso.eurostat.ec.europa.eu/ [naida_10_gdp]; [env_air_gge], and http://ec.europa.eu/eurostat/web/population-demography-migration-projections/populationdata/main-tables/ [tps00001]), accessed on 1.10.2016. 
Figure 1. Europe: GDP per capita relative to the US, constant US\$ (PPP), 1995-2015

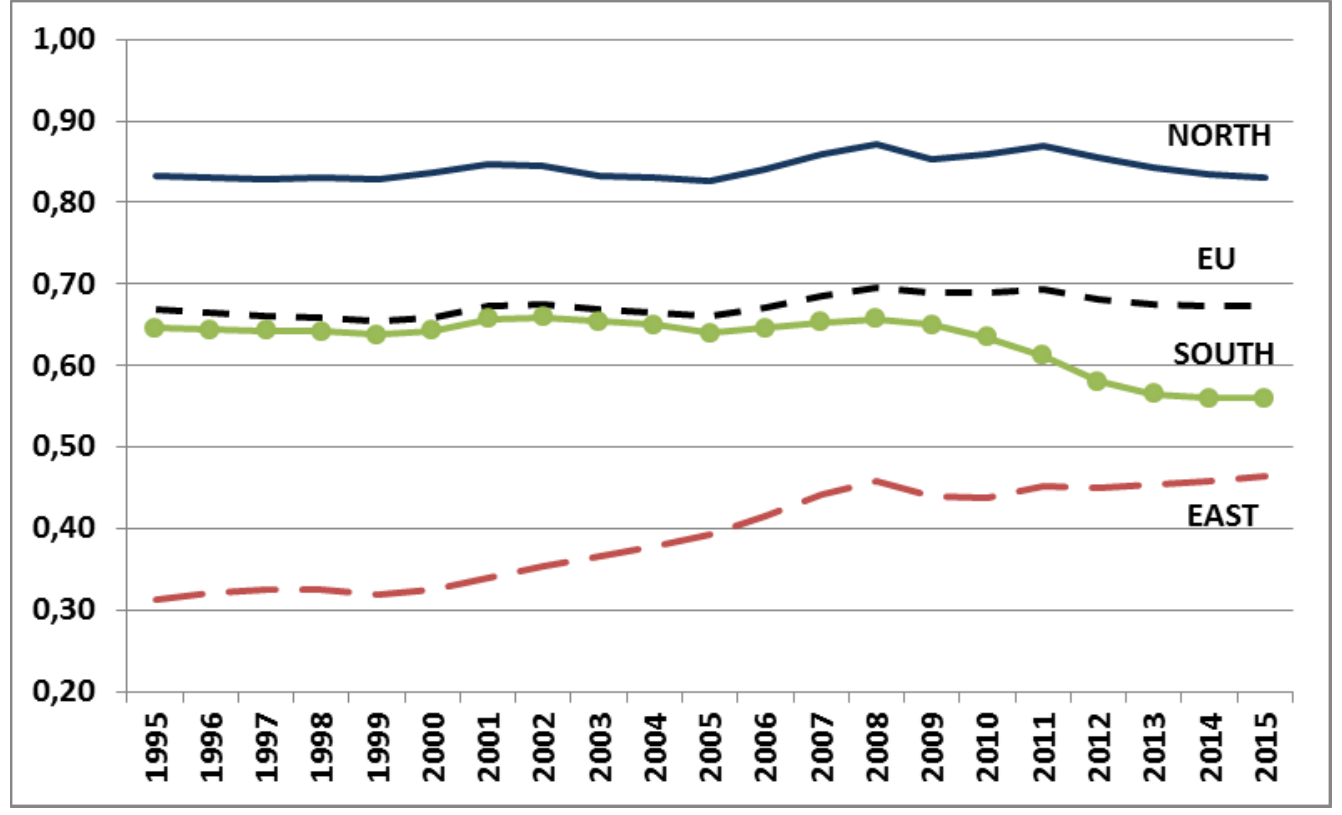

Note. Authors' calculations on GDP per capita, in constant US\$ (PPP-adjusted) at 2011 price levels, based on data from the World Bank (http://data.worldbank.org/indicator/NY.GDP.PCAP.PP.KD), accessed on 1.10.2016. EU includes all member countries, NORTH consists of Denmark, Sweden, Finland, Germany, Netherlands and Austria; SOUTH comprises Greece, Italy, Portugal and Spain; while EAST includes the 11 previously socialist countries in the East of Europe (that became members after the collapse of the Soviet Union). 
Figure 2. Europe: Change in Rates of Youth Unemployment (20-24 years) 2007-2015

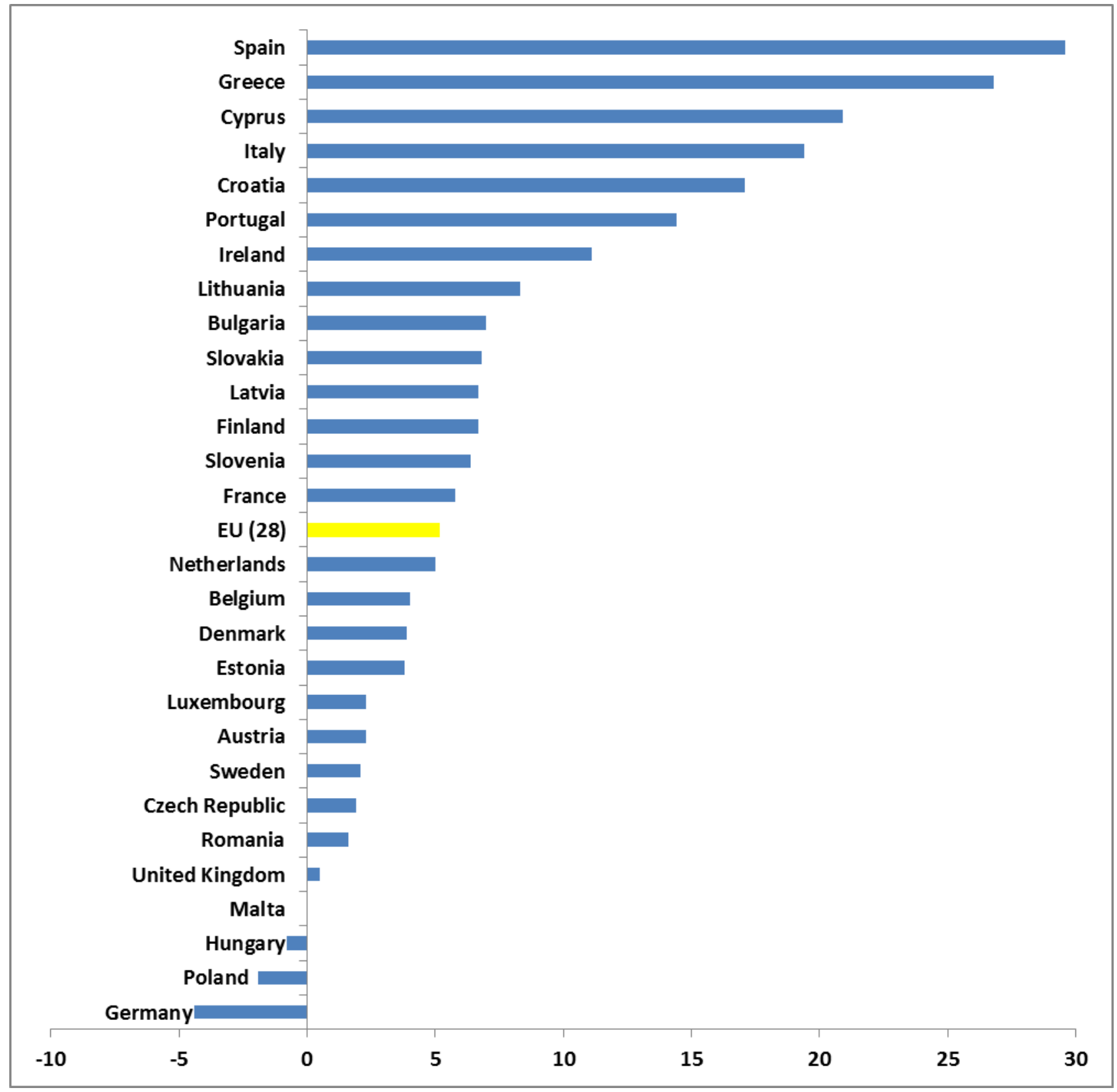

Note. Authors' calculations based on data from Eurostat (http://appsso.eurostat.ec.europa.eu/ (yth_empl_090)), accessed on 1.10.2016. 
Figure 3. GHG emissions, EU28, 1990-2014

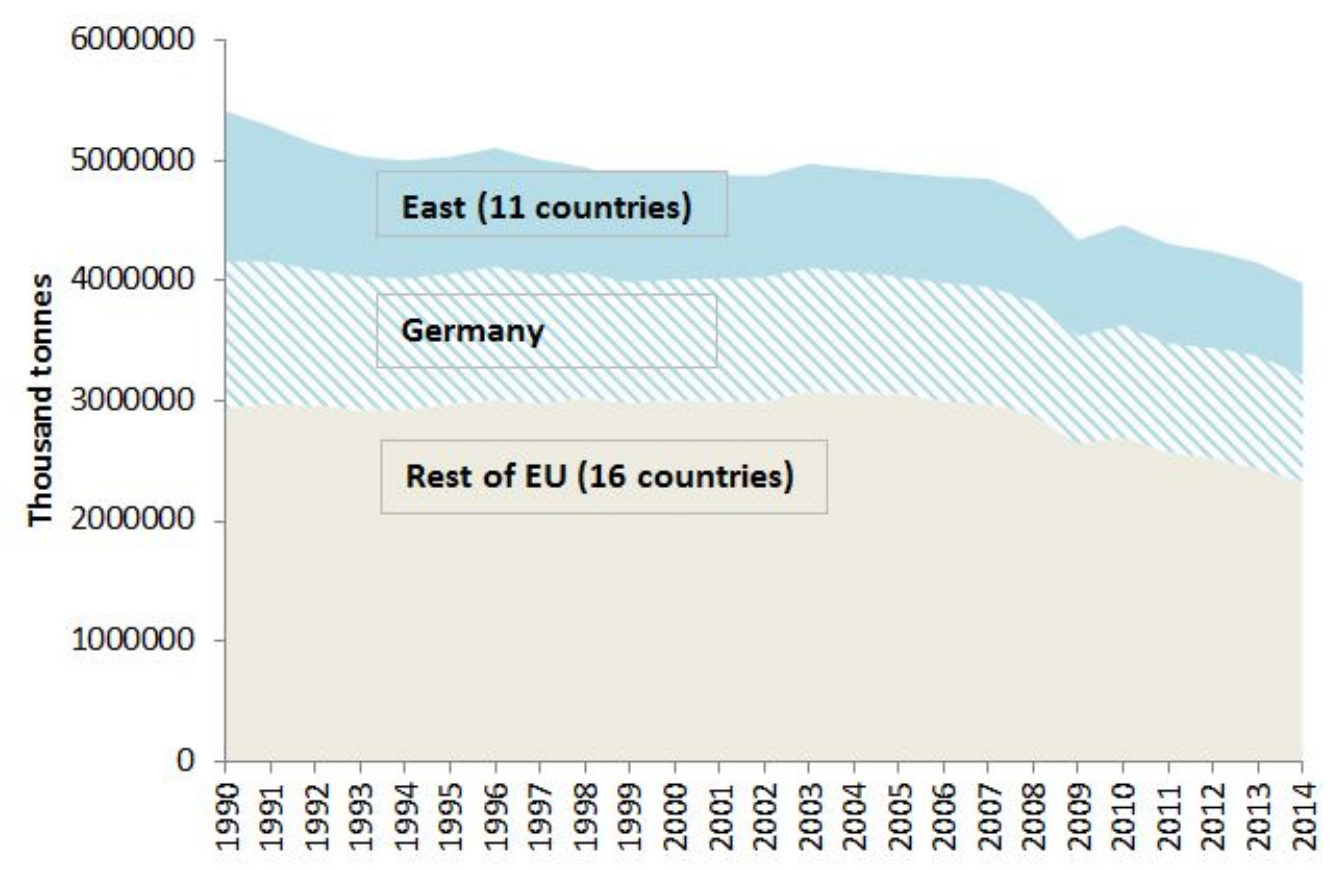

Note: Authors' calculations based on data from Eurostat (http://appsso.eurostat.ec.europa.eu/ [env_air_gge], accessed on 1.10 .2016 
Figure 4. GDP and GHG emissions, EU28, 1995-2014

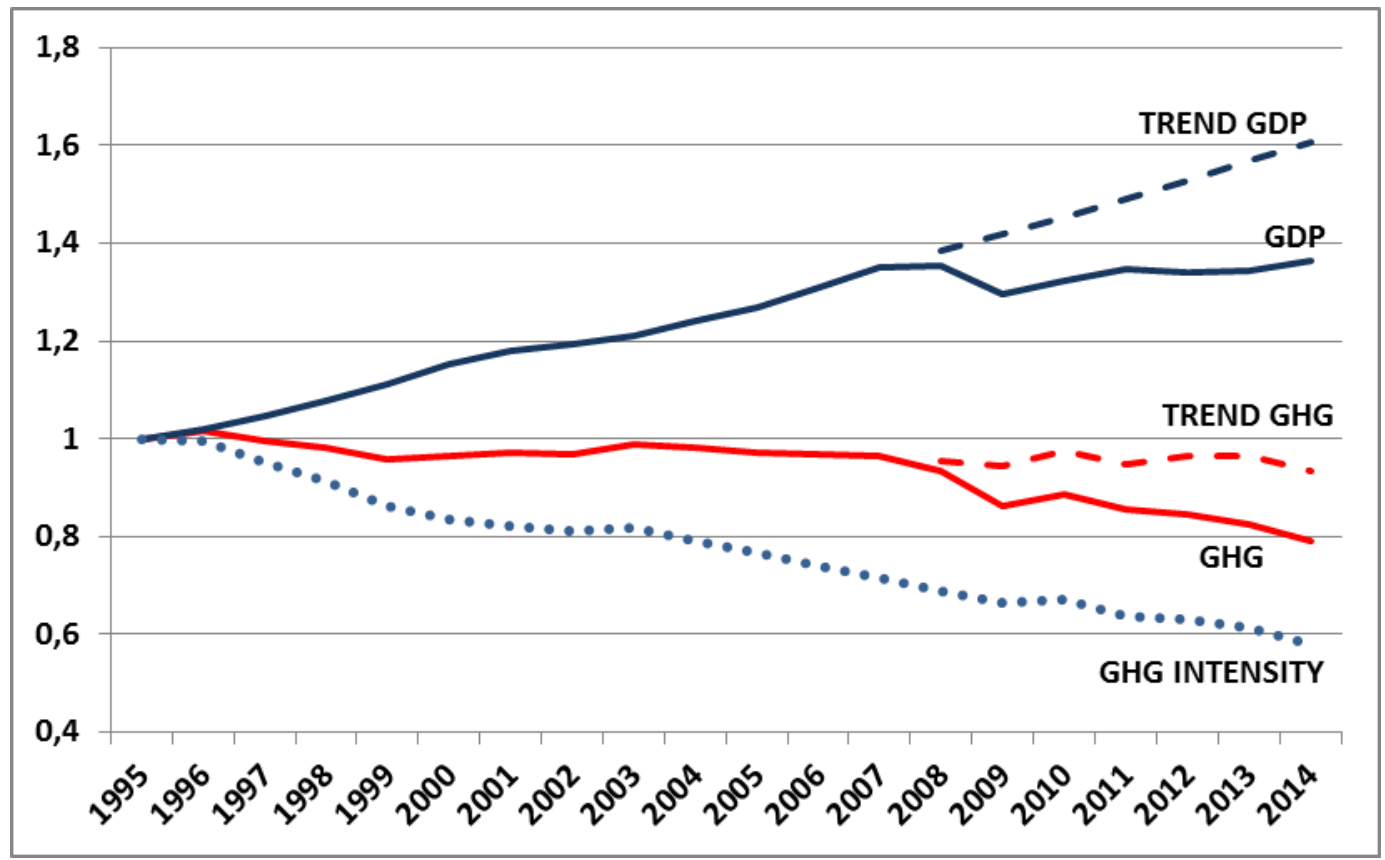

Note: Authors' calculations based on data from Eurostat (http://appsso.eurostat.ec.europa.eu/ [nama_10_gdp] and [env_air_gge], accessed on 1.10.2016). Trend-GDP is a continuation of the 1995-2007 trend for GDP, while Trend-GHG is what the emissions would have been in that case (with actual GHG intensity).

Figure 5. R\&D as share of GDP, 1996-2014

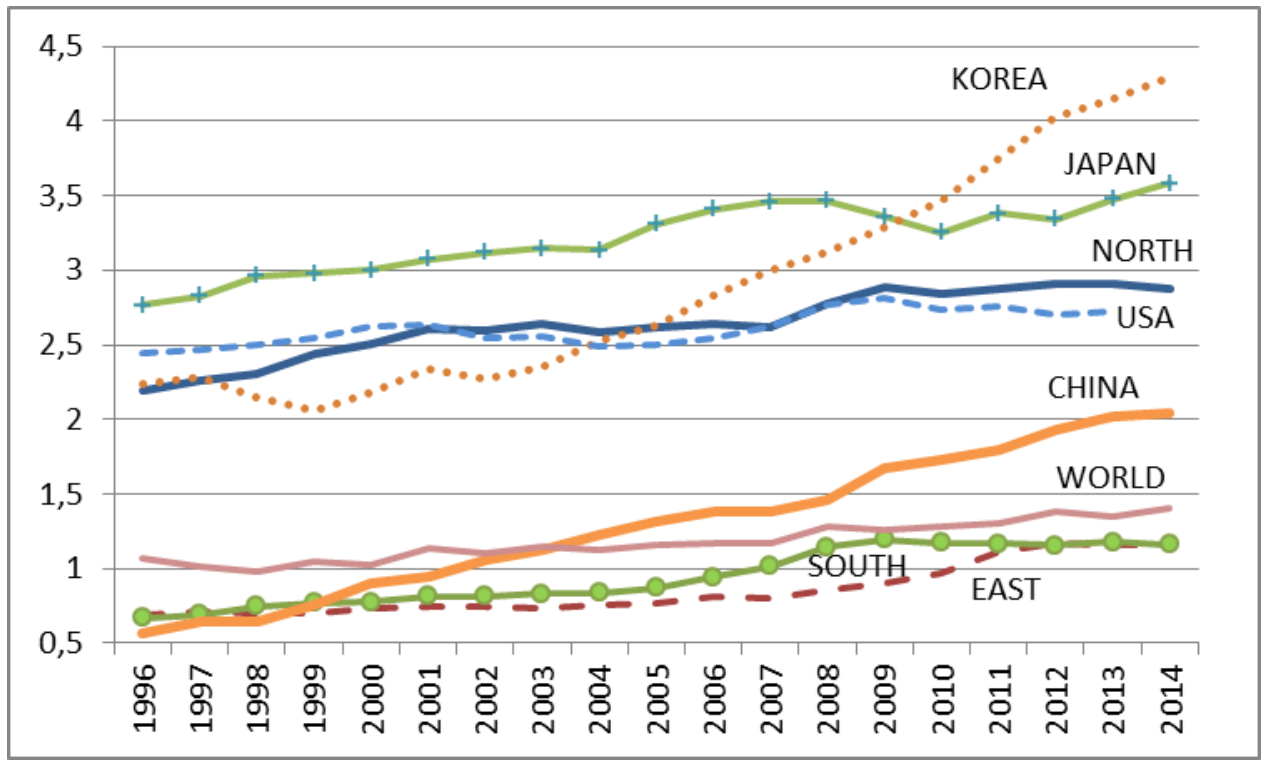


Note: Authors' calculations based on data from data from UNESCO ( http://data.uis.unesco.org/), accessed on 1.10.2016. "WORLD" is the average value for the 64 countries for which reasonably comprehensive data exist. NORTH, EAST and SOUTH are groups of European countries (for definitions see note to Figure 1).

Figure 6. Europe: Fertility-rates (live births per woman), 1970-2014

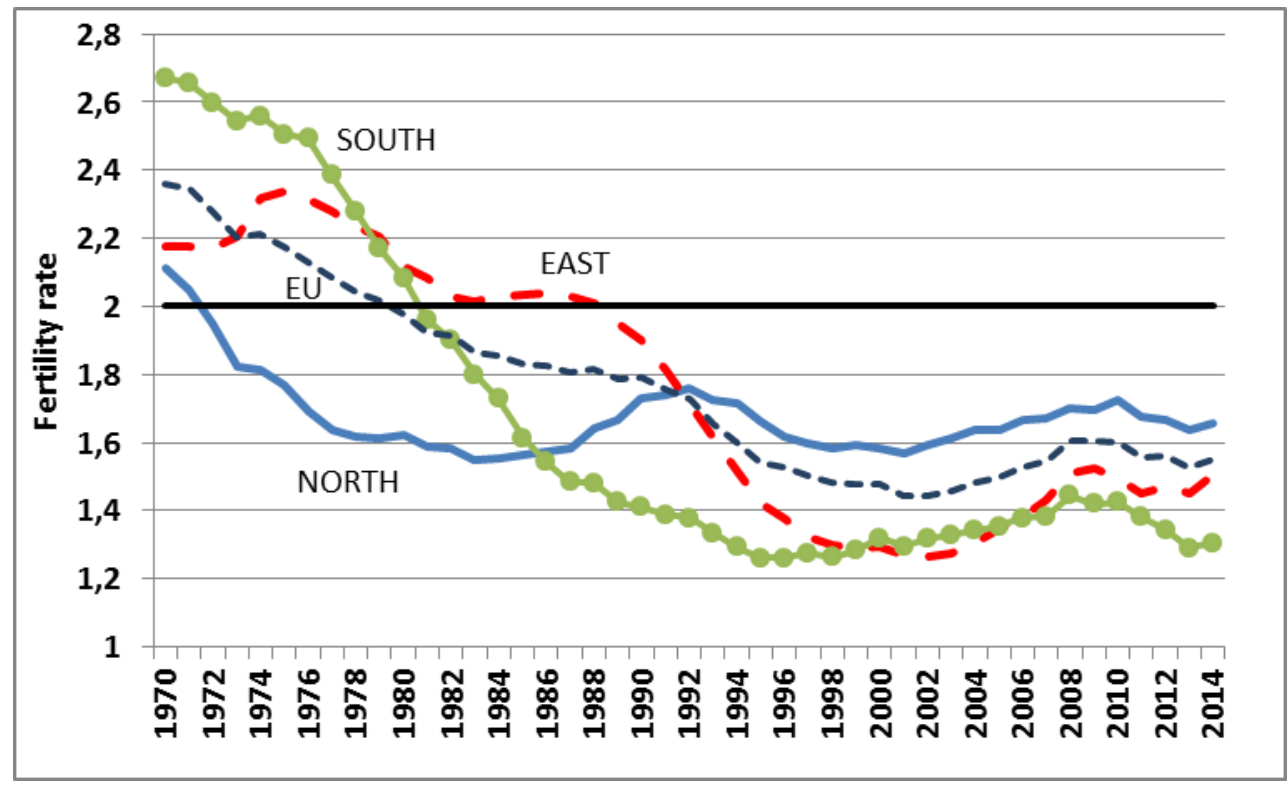

Note: Authors' calculations based on data from Eurostat (http://appsso.eurostat.ec.europa.eu/[demo frate]), accessed on 1.10.2016.

\section{(alternative version of Figure 6)}

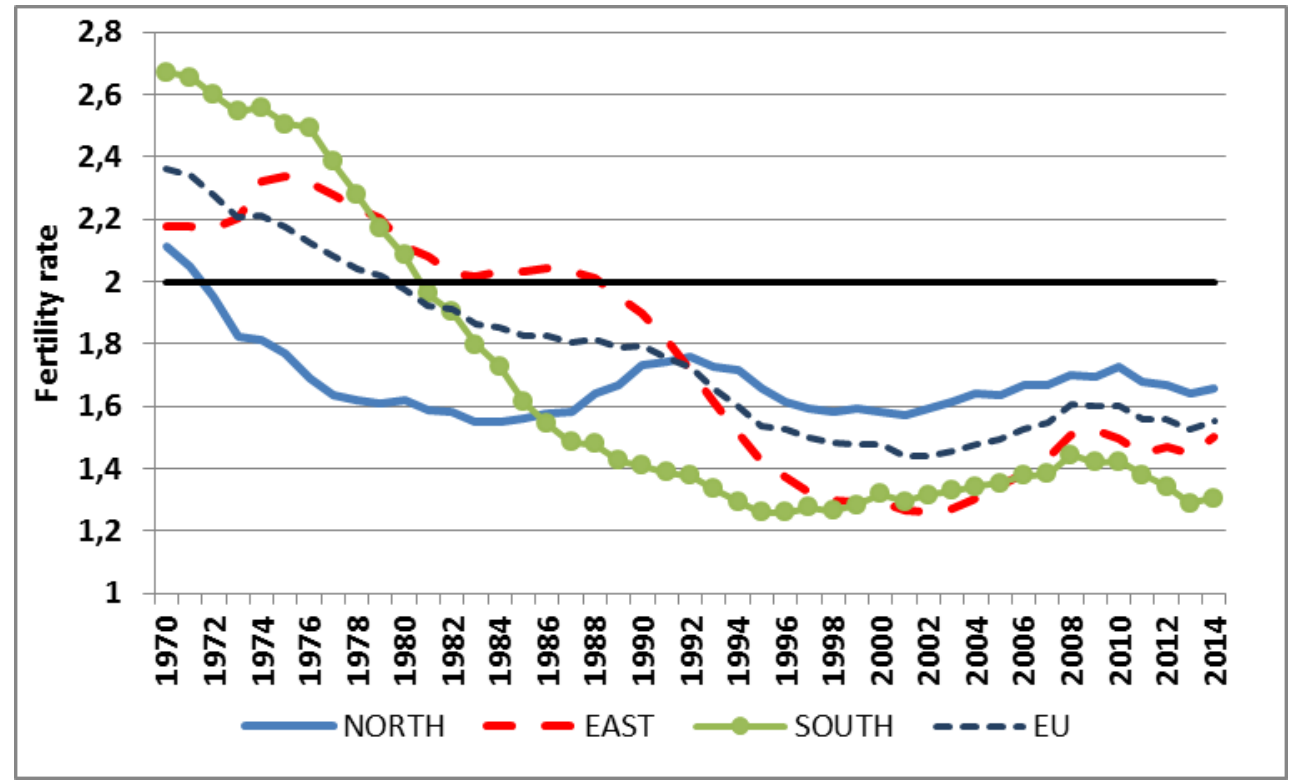


Figure 7. Inequality (gini-coeffecient), total population, 2013

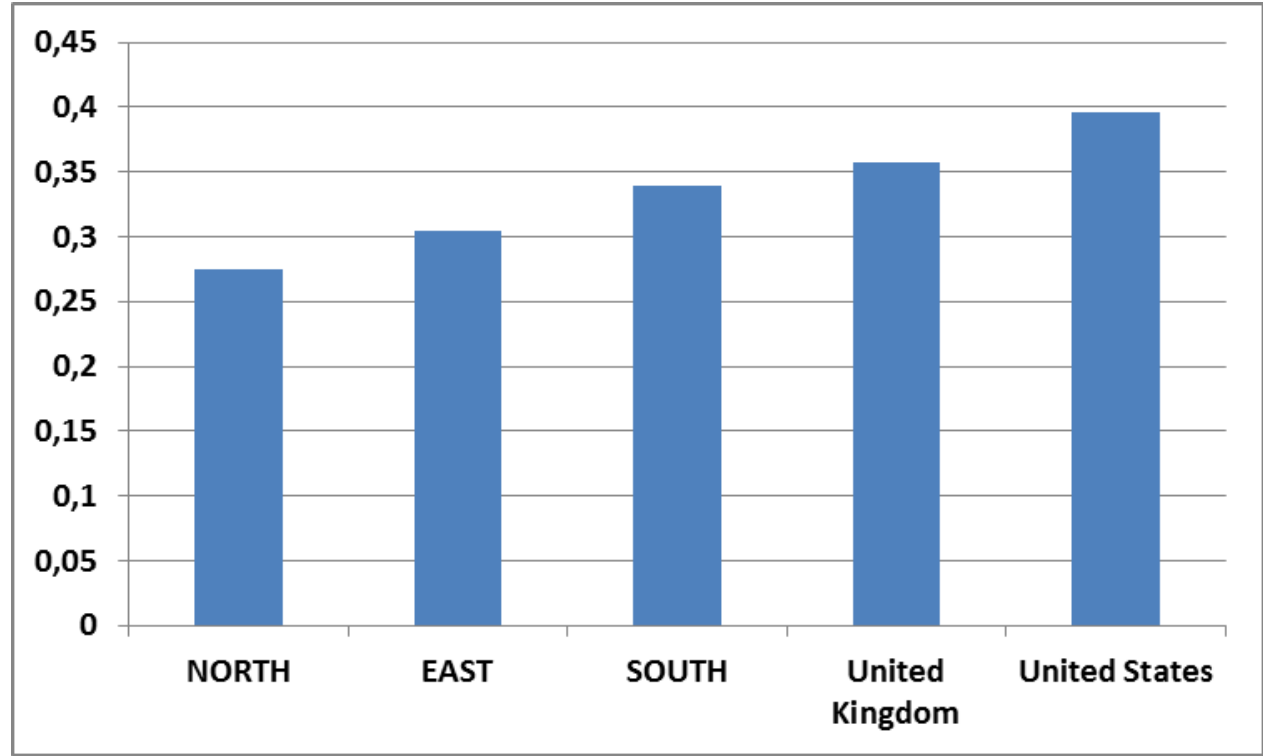

Note: Authors' calculations based on data from OECD Income Distribution Database (IDD),

http://www.oecd.org/social/income-distribution-database.htm, accessed on 1.10.2016. The coefficient is for disposable income (post taxes and transfers). 
Figure 8. Renewables as a share of total German electricity consumption, 1990-2015

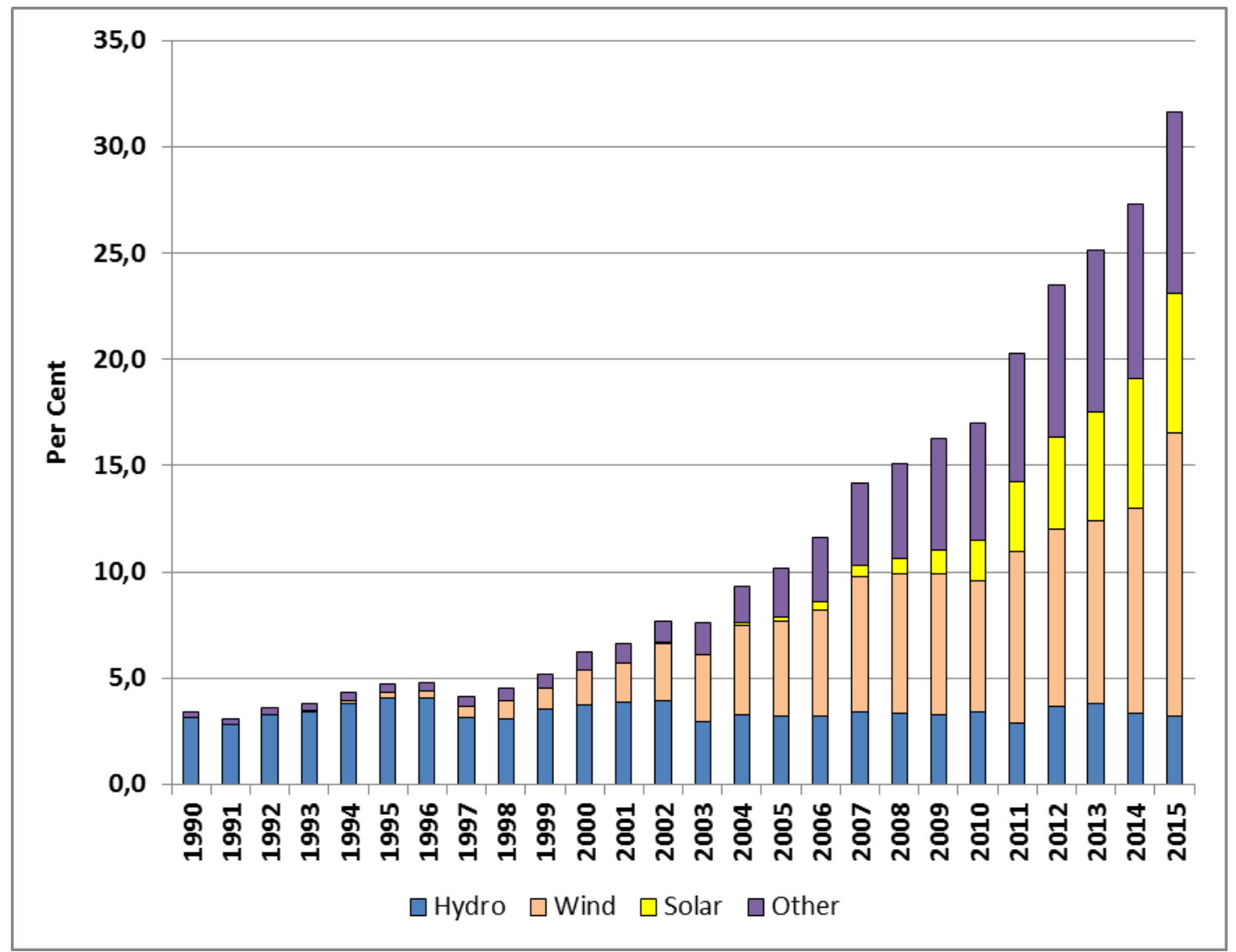

Note: Authors' calculations based on data from Bundesminister für Wirtschaft und Energie,

(http://www.bmwi.de/DE/Themen/Energie/Energiedaten-und-analysen/Energiedaten/gesamtausgabe), accessed on 1.10 .2016 
Figure 9. GHG intensity and GDP per capita, EU28, 2014

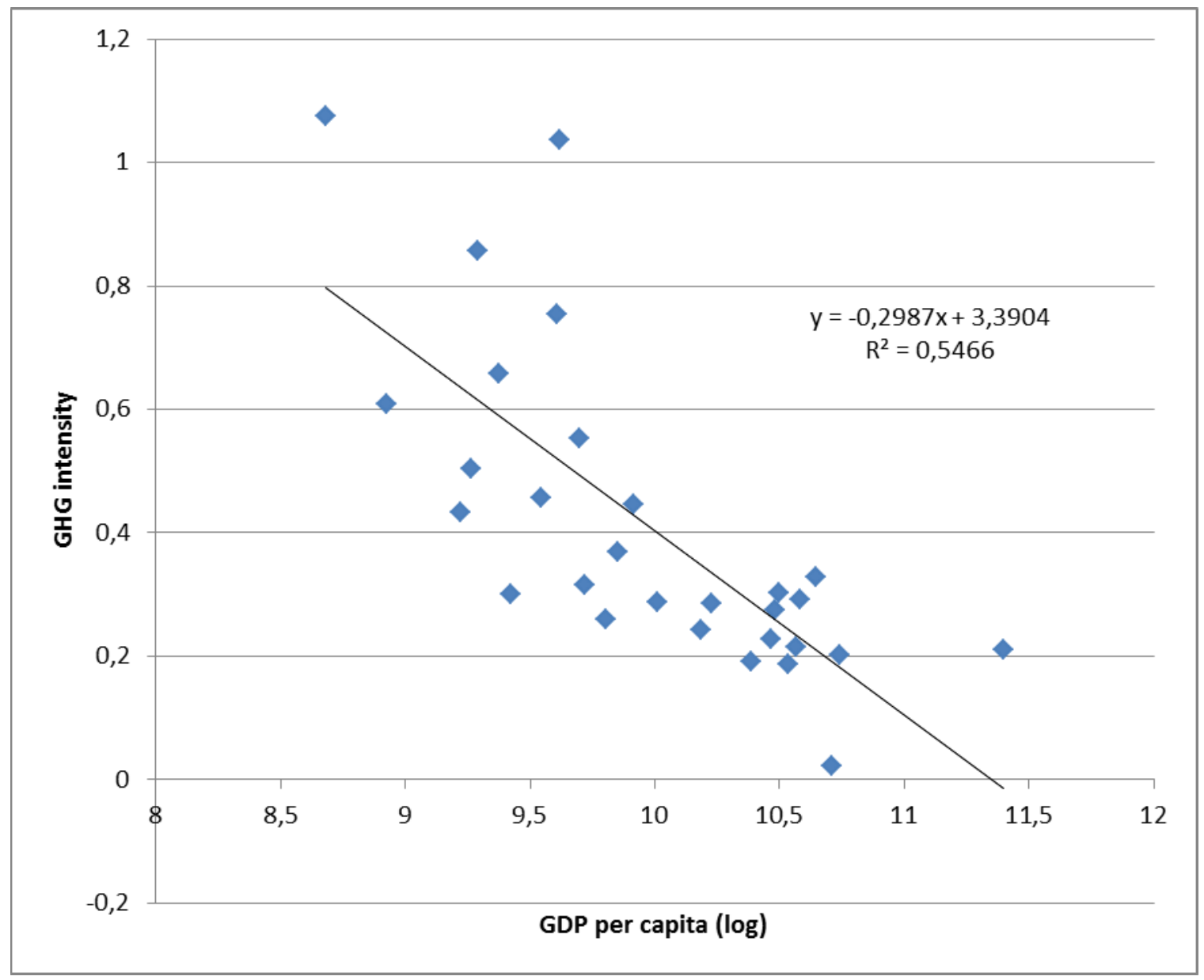

Note: Authors' calculations based on data from Eurostat (http://appsso.eurostat.ec.europa.eu/ [naida_10_gdp]; [env_air_gge], and http://ec.europa.eu/eurostat/web/population-demography-migration-projections/populationdata/main-tables/ [tps00001]), accessed on 1.10.2016. 